\title{
Comparative effectiveness of common therapies for Wilson disease: A Systematic review and meta-analysis of controlled studies
}

Christian Appenzeller-Herzog ${ }^{1}$, Tim Mathes ${ }^{2}$, Marlies L. S. Heeres ${ }^{3}$, Karl Heinz Weiss ${ }^{4}$, Roderick H. J. Houwen ${ }^{3}$, Hannah Ewald ${ }^{1,5}$

${ }^{1}$ University Medical Library, University of Basel, Basel, Switzerland

${ }^{2}$ Institute for Research in Operative Medicine, Faculty of Health, School of Medicine, Witten/Herdecke University, Cologne, Germany

${ }^{3}$ Wilhelmina Children's Hospital, University Medical Center Utrecht, Netherlands

${ }^{4}$ Department of Internal Medicine IV, Medical University of Heidelberg, Heidelberg, Germany

${ }^{5}$ Basel Institute for Clinical Epidemiology and Biostatistics, Department of Clinical Research, University Hospital Basel and University of Basel, Basel, Switzerland

To whom correspondence should be addressed:

Hannah Ewald

Tel: +41612075564

Fax: not available

Email: $\underline{\text { hannah.ewald@unibas.ch }}$

Word count: 5320

Figures: $\quad 3$ main figures, 3 supplementary figures

Tables: $\quad 2$ main tables, 5 supplementary tables

Abbreviations: WD, Wilson disease; DPen, D-penicillamine; Zn, zinc salts; TTM, tetrathiomolybdate; OLT, orthotopic liver transplantation; NOS, Newcastle-Ottawa scale; OR, odds ratio; $\mathrm{Cl}$, confidence interval

Financial support: There was no specific external funding supporting this work. 
Conflict of Interest Statement: Four of the included reports are authored by KHW and one by RHJH. KHW is a consultant at Ipsen, Eisai, Chiesi, Vivet therapeutics, GMP-O, Univar, Wilson therapeutics, and BMS, a contract researcher of Univar, Wilson therapeutics, Novartis, QED, Alexion, and GMP-O, and served as a speaker at Novartis, Alexion, Falk, and Abbvie. RHJH served on an advisory board for Univar. All other authors declare no financial relationships with any organizations that might have an interest in the submitted work.

Authorship Statement: $\mathrm{CAH}$ and $\mathrm{HE}$ are the guarantors. $\mathrm{CAH}, \mathrm{HE}$, and $\mathrm{RHJH}$ conceived the study. $\mathrm{CAH}$ and $\mathrm{HE}$ conducted the literature searches. $\mathrm{CAH}, \mathrm{HE}, \mathrm{MLSH}$, and $\mathrm{RHJH}$ selected included studies. $\mathrm{CAH}$ and KHW extracted the data, HE checked extractions. TM analyzed the data. $\mathrm{CAH}, \mathrm{HE}$, and TM interpreted the results. CAH wrote the first draft and all authors made revisions on the manuscript. All authors read and approved the final version of the article including the authorship list. 


\section{Abstract}

BACKGROUND \& AIMS: Wilson disease (WD) is a rare disorder of copper metabolism. The objective of this systematic review is to determine the comparative effectiveness and safety of common treatments of WD.

METHODS: We included WD patients of any age or stage and the study drugs D-penicillamine, zinc salts, trientine, and tetrathiomolybdate. The control could be placebo, no treatment, or any other treatment. We included prospective, retrospective, randomized, and non-randomized studies. We searched Medline and Embase via Ovid, the Cochrane Central Register of Controlled Trials, and screened reference lists of included articles. Where possible, we applied random-effects metaanalyses.

RESULTS: The 23 included studies reported on 2055 patients and mostly compared D-penicillamine to no treatment, zinc, trientine, or succimer. One study compared tetrathiomolybdate and trientine. Post-decoppering maintenance therapy was addressed in one study only. Eleven of 23 studies were of low quality. When compared to no treatment, D-penicillamine was associated with a lower mortality (odds ratio $0.013 ; 95 \% \mathrm{Cl} 0.0010$ to 0.17 ). When compared to zinc, there was no association with mortality (odds ratio $0.73 ; 95 \% \mathrm{Cl} 0.16$ to 3.40 ) and prevention or amelioration of clinical symptoms (odds ratio $0.84 ; 95 \% \mathrm{Cl} 0.48$ to 1.48 ). Conversely, D-penicillamine may have a greater impact on side effects and treatment discontinuations than zinc.

CONCLUSIONS: There are some indications that zinc is safer than D-penicillamine therapy while being similarly effective in preventing or reducing hepatic or neurologic WD symptoms. Study quality was low warranting cautious interpretation of our findings.

Word count: 244

Keywords: Wilson disease; Hepatolenticular degeneration; Systematic review; Meta-Analysis 


\section{Introduction}

Wilson disease (WD), also known as hepatolenticular degeneration, is an autosomal recessively inherited disorder of copper metabolism. ${ }^{1,2}$ It is caused by mutations in ATP7B, which encodes a copper transporting ATPase that is expressed in the liver. ${ }^{3}$ ATP7B-mediated copper translocation is essential for the excretion of copper into the bile. Defective ATP7B function will therefore result in a gradually increasing copper concentration in the liver, which ultimately exceeds natural buffering capacity. ${ }^{1}$ At that point, patients may develop acute liver failure, sometimes accompanied with hemolytic anemia, due to the release of unbound copper from the liver into the circulation. ${ }^{4}$ In other patients, liver disease develops more gradually. Copper will also disseminate to other organs, most notably the brain, where it causes a characteristic movement disorder. ${ }^{5}$ This is due to copper deposition in the basal ganglia, which are most severely affected, but a range of other neurological and/or psychological symptoms may also develop in response to copper overload. ${ }^{5}$

None of the available medical treatments for WD can cure the disease and all require a life-long oral regimen. They aim at reducing copper overload in the body, either by the copper chelators Dpenicillamine (DPen $)^{6}$ or trientine, ${ }^{7}$ which immediately increase urinary copper excretion, or by zinc salts $(Z n),{ }^{8,9}$ which inhibit intestinal copper absorption through slow transcriptional induction of cellular metallothioneins. ${ }^{10}$ After a lag phase, $\mathrm{Zn}$ also induces net excretion of copper from the body. ${ }^{11}$ Another important, emerging treatment is tetrathiomolybdate (TTM) which binds excess copper and promotes biliary copper excretion. ${ }^{12}$ Contrary to DPen and trientine, it not only captures free plasma copper but seems to have an additional protective activity component within cells. ${ }^{13}$ As it was too unstable for routine application in its original formulation as ammonium salt, it was never used widely. This may, however, change since a stable bis-choline salt has been developed and implemented recently. ${ }^{14,} 15$ Irrespective of the drug used, the therapy of WD can be divided into an initial decoppering phase with a negative copper balance and a subsequent maintenance phase where intake and excretion of copper roughly balance each other. ${ }^{1}$ Likewise, all of the copper-lowering drugs strongly require good compliance with treatment to be successful. ${ }^{16}$ 
The choice between a chelator and $\mathrm{Zn}$ for the treatment of copper overload in patients with WD is not straightforward. Owing to the low incidence and heterogeneous symptomatology of WD, ${ }^{1}$ the design and realization of clinical trials that compare the effectiveness of available treatment options is extraordinarily challenging. Thus, clinical decisions often rely more on the patient's or physician's preference or drug availability than on evidence. Probably mostly owing to the fact that DPen was introduced as a successful treatment for WD in the late 1950s - at least 30 years before any other treatment used today ${ }^{6}-$ it has remained the standard of care for WD patients in most countries. ${ }^{17}$ The dominance of DPen or, more generally, chelator therapy is also reflected in current guidelines..$^{18-21}$ These suggest that symptomatic patients should be treated with a chelating agent, although Zn may be used as first-line therapy in those with neurological disease. ${ }^{18-21}$ In presymptomatic patients, either a chelator or $\mathrm{Zn}$ can be used. ${ }^{18-21}$ These recommendations were partly based on a systematic review on initial treatment of WD from 2009 that included all studies published at that time describing outcome, both controlled and non-controlled. ${ }^{22}$ This systematic review was limited by the small number of symptomatic patients that were treated with Zn. Still, it suggested that severe side effects necessitating drug withdrawal were more frequent on DPen than on $\mathrm{Zn} .{ }^{22}$ Also, neurologic deterioration after the start of decoppering therapy appeared to occur more frequently when using DPen as compared to $\mathrm{Zn} .^{22}$

As a number of new studies that compared different treatments of WD have been published since 2009, we now performed a systematic review focusing on controlled studies only. The aim of this systematic review is to assess the comparative effectiveness of common WD therapies on patientrelevant outcomes.

\section{Materials and methods}

\section{Eligibility criteria}

We included WD patients of any age or stage. The study drug had to be one of four established therapies, namely DPen, trientine, TTM, or Zn. The control could be placebo, no treatment, or any 
other treatment that does not include the respective study drug (e.g. Zn versus trientine was allowed, Zn $50 \mathrm{mg}$ versus $\mathrm{Zn} 100 \mathrm{mg}$ was not). Concomitant therapies had to be identical in the compared treatment arms (e.g. trientine plus Zn versus TTM plus Zn). Comparisons between monotherapy and combination therapy regimens that included the respective monotherapy drug (e.g. DPen plus $\mathrm{Zn}$ versus $\mathrm{Zn}$ ) have been analyzed elsewhere ${ }^{23}$ and were not considered any further here. We included studies that reported all-cause mortality, orthotopic liver transplantation (OLT), neurological symptoms (e.g. dystonia, dysarthria, cognitive decline, drooling, tremor, gait disturbance, chorea, seizure, psychosis), liver-related symptoms (e.g. icterus, ascites, steatosis, fibrosis, mild hepatitis, acute liver failure, cirrhosis, serum transaminases), adverse effects (e.g. dermatologic manifestations, nephrotoxicity, pulmonary toxicity, autoimmune disorders, anemia, neutrophilic agranulocytosis, thrombocytopenia, hypothyroidism, liver dysfunction, colitis, status dystonicus, myasthenia gravis, arthropathy, macromastia, early neurologic deterioration, gastrointestinal irritation), and frequency of treatment discontinuation (i.e. switching to another drug, stopping or changing the treatment). We included prospective and retrospective studies, including randomized, non-randomized controlled trials, and comparative observational studies that were written in English, German, Dutch, French, Spanish, or Portuguese. Animal studies, case reports, case series, cross-sectional studies, before-after studies, reviews, letters, abstract-only publications, editorials, diagnostic or other testing studies, and non-controlled studies were excluded. No publication date restrictions were applied.

\section{Identification of relevant literature}

\section{Electronic searches}

Two information specialists (CA-H, HE) developed the search strategy. Text words (synonyms and word variations) and database-specific subject headings for WD, DPen, trientine, $\mathrm{Zn}$, and TTM were used. We searched the electronic databases Medline and Embase via Ovid, and the Cochrane Central Register of Controlled Trials (CENTRAL) (last search January 31, 2019) (Appendix 1). All retrieved references were exported to Endnote X8 and deduplicated. 


\section{Searching other resources}

To identify possible additional studies that escaped our electronic database searches, we screened the reference lists of the full-text papers of all included articles and of key systematic reviews (backward citation chasing). ${ }^{24}$ For this purpose, we retrieved systematic reviews during title abstract screening that had a similar research question as we do, and that were described as "systematic (literature) review" (semantic variations allowed) or that described a systematic literature search in their methods section. ${ }^{22,23,25-31}$

\section{Data collection and analysis}

\section{Study selection}

Two reviewers (HE, CA-H) independently pilot-screened the first 200 references, the rest were screened by one reviewer (CA-H). Any uncertainties were solved by discussion (HE, CA-H). All potentially relevant references were retrieved in full-text and independently assessed by two reviewers $(\mathrm{CA}-\mathrm{H}, \mathrm{RHJH})$. Any disagreements over eligibility were resolved by consensus. Where necessary, a third review author (HE) made a final judgement. We recorded the selection process and the reasons for exclusion of full-text articles were documented in a characteristics of excluded studies table (Table S1). Among included records, multiple publications on the same study were collated.

\section{Data extraction and management}

Study characteristics and data on predefined outcomes (see "Eligibility criteria") from included studies were extracted by one reviewer $(\mathrm{CA}-\mathrm{H})$, the accuracy and correctness of the extractions were verified by a second reviewer (HE), and disagreements were resolved by consensus. Due to a high heterogeneity in outcome reporting, we used the term "asymptomatic/improved" whenever the interventional drug prevented or improved neurological or liver-related symptoms. For assessment of "asymptomatic/improved" events, there was no distinction between symptom relief and symptom improvement. Where available, outcome data was extracted in conjunction with the clinical presentation of the patients at diagnosis as reported by the authors, i.e. presymptomatic patients 
(without clinical manifestations), and patients with hepatic, hepato-neurologic, or neurologic manifestations. When study cohorts included drug switcher patients, we considered patient data only for the first-line treatments until the time of drug switch. If the outcome was not reported at the time of drug switch, we censored the patient from that outcome analysis. However, for the extraction of mortality and OLT, we included all patients and grouped them according to their first-line treatments (according to the intention-to-treat principle). From two studies, ${ }^{32,}{ }^{33}$ outcome data of first-line treatments were re-extracted from clinical files by one reviewer (KHW).

\section{Assessment of risk of bias in included studies}

The quality of included observational studies and non-randomized trials was assessed on study level using the Newcastle-Ottawa scale (NOS) for cohort studies by one reviewer (CA-H). The scale applies a semi-quantitative star system ( 0 - 9 stars, with more stars indicating higher quality) to estimate study quality in the three domains subject selection, comparability of cohorts, and assessment of outcome. ${ }^{34}$ Quality appraisal of randomized controlled trials was conducted using the RoB 2.0 tool which was developed by the Cochrane collaboration. ${ }^{35}$

\section{Statistical analysis}

We performed a meta-analysis for pooling odds ratios (ORs) for studies that were considered sufficiently clinical homogenous. The primary outcomes were mortality and asymptomatic/improved, the secondary outcomes side effects, early neurologic deterioration, treatment discontinuation, and OLT. In the case that at least six studies without zero events could be included in the meta-analysis, ${ }^{36,}$ ${ }^{37}$ we performed inverse-variance random effects meta-analyses using the Paule-Mandel between study heterogeneity estimator with modified Hartung-Knapp confidence intervals (Cls). ${ }^{38,}{ }^{39}$ For consistency, we used the same model for sensitivity analyses irrespective of the number of studies. For any comparison with zero events or less than six included studies, we used beta-binomial models which show satisfactory statistical properties for pooling sparse data..$^{40}$ In addition to the beta-binomial models, we performed sensitivity analyses using the Peto-Method because effect estimates and confidence intervals can strongly depend on the applied meta-analytic method in sparse data and 
unbalanced study arm situations. ${ }^{41}$ For all pooled ORs, we calculated $95 \% \mathrm{Cls}$. Statistical heterogeneity was quantified with $\mathrm{I}^{2} .42$ If the $\mathrm{I}^{2}$ value was $>0 \%$, we calculated $95 \%$ prediction intervals in addition to the $95 \% \mathrm{Cls} .{ }^{43}$ We performed sensitivity analyses according to methodological study quality if at least five moderate to high quality studies (NOS score $<6$ as was rated as low quality and $\geq 6$ as moderate to high quality ${ }^{44}$ ) were available. Subgroup analyses according to clinical presentation were added when at least three studies reported subgroup-specific outcome data. We could not prepare funnel-plots because all comparisons included less than ten studies.

For inverse-variance random effects and Peto-odds-ratios meta-analyses, we used the $\mathrm{R}$ package meta. ${ }^{45}$ We performed meta-analyses based beta-binomial models with $\mathrm{SAS}^{\odot}$ Version 9.4. For the graphical representation of beta-binomial analyses, we generated forest plots in $\mathrm{R}$ using the fixedeffect inverse variance model and manually inserted the summary OR derived from the beta-binomial model.

\section{Results}

\section{Results of the search and study characteristics}

Our electronic searches identified 3453 records and three potentially eligible additional records were found using backward citation chasing. Eight potentially relevant records were excluded due to foreign language. ${ }^{46-53} \mathrm{~A}$ total of 174 records were selected for full-text screening to assess eligibility. Of these, 26 publications reporting on 23 studies met our inclusion criteria (Figure 1)..$^{17,26,32,33,54-73}$ Reasons for exclusion of the 148 studies are shown in Table S1.

The included studies were published between 1968 and 2018. Seventeen were retrospective observational studies, three were prospective observational studies, two were non-randomized controlled trials, and one was a randomized controlled trial (Table 1). Given the substantial ambiguity in the classification of observational studies, ${ }^{74}$ we refrained from defining observational study designs any further. 
From the included studies (Table 1), four compared the use of DPen with no treatment ${ }^{54-56,59}$ (of which one study ${ }^{55}$ used a mixture of DPen and L-penicillamine, the less-active stereoisomer of DPen). Four compared DPen with trientine or Zn, ${ }^{33,70,73,75}$ eleven compared DPen with $\mathrm{Zn},{ }^{17,}, 26,57,60,62,64,67-69,71,76$ and two DPen with trientine. ${ }^{32,61}$ Finally, two stand-alone studies evaluated the performance of DPen versus succimer treatment during maintenance phas $\mathrm{e}^{58}$ and trientine versus TTM treatment as initial therapy, ${ }^{63}$ respectively. In both studies, all patients received $\mathrm{Zn}$ treatment concomitantly to the drugs under evaluation. Only two ${ }^{57,64}$ of the 26 included publications were already analyzed in the previous systematic review on optimal initial treatment of Wilson's disease. ${ }^{22}$

The studies included 2055 patients, whereas a partial overlap of cohorts was identified between three studies from Heidelberg, Germany, ${ }^{32,33,73}$ and two studies from Naples, Italy. ${ }^{60,71}$ Some studies exclusively included presymptomatic, ${ }^{55}$ hepatic, $^{26,59,71,76}$ neurologic, $^{63}$ or symptomatic ${ }^{17,64,67,70}$ (i.e. $^{2}$ with any manifestations) patients (Table 1 ). The age range across all studies was 1 to 66 years; 17/23 studies included mixed populations while five studies reported on children ${ }^{60,71}$ or adults $^{17,68,76}$ only.

Mortality, 17, 54-57, 59, 61-64, 71, 76 "asymptomatic/improved", 17, 32, 33, 54, 57, 58, 60, 64, 68, 69, 71 side effects, , $^{32,33,57,58,}$ $60,61,63,64,68,69,71$ and treatment discontinuation $17,32,33,57,58,60,61,64,68,69,71,75,76$ were the most prevalent outcomes, followed by OLT OS-61, 64, 69, 71, 76 and neurologic deterioration $^{17,32,33,63,64,71}$ (Table 1). Data on fibrosis progression, ${ }^{26,70}$ development of autoimmune diseases, ${ }^{73}$ and 15 -year probability of survival ${ }^{67}$ were reported in stand-alone studies only. The maintenance phase of drug therapy was specifically addressed in only one study. ${ }^{58}$

\section{Methodological study quality rating}

The NOS scores ranged between 2 and 8 with a median score of 5.5 (Table S2), indicating that only a subset of studies were of high or moderate quality. Potential problems with the representativeness of included patients and comparability of patients between different treatment arms (selection bias) were identified in 9 of 21 studies (38\%). ${ }^{26,33,56,59,61,67,69,71,76}$ Only four studies reached a NOS score > 7, which is indicative of high reliability. ${ }^{17,54,57,70}$ Adjusting for confounding factors was reported in only 
one study. ${ }^{17}$ Quality assessment of Brewer et al. ${ }^{63}$ using RoB 2.0 identified some concerns with regard to bias due to the randomization process, due to missing outcome data, and in the selection of the reported results (Table S2).

\section{Data synthesis and analysis}

\section{D-Penicillamine versus no treatment}

In the four studies comparing DPen-treated and untreated WD patients, ${ }^{54-56,59}$ the pooled OR for death was 0.013 (95\% $\mathrm{Cl} 0.0010$ to $0.17 ; I^{2}=31 \%$; Figure 2 , Table 2$)$. The pooled OR for remaining or becoming asymptomatic was $22.3\left(95 \% \mathrm{Cl} 0.40\right.$ to $>100 ; I^{2}=86 \%$; Table 2$) .54-56$ Other outcomes were not reported for this comparison. Due to the low number of studies no sensitivity or subgroup analyses were performed.

\section{D-Penicillamine versus zinc salts}

The pooled OR for mortality from seven studies ${ }^{17,33,57,62,64,71,76}$ was 0.73 (95\% Cl 0.16 to $3.40 ; I^{2}=37 \%$; Figure $3 \mathrm{~A}$, Table 2). For the asymptomatic/improved outcome, meta-analysis of seven studies ${ }^{17,33,57,}$ $60,64,68,69$ yielded an OR of $0.84\left(95 \% \mathrm{Cl} 0.48\right.$ to $1.48 ; \mathrm{I}^{2}=0 \%$; Figure $3 \mathrm{~B}$, Table 2$)$.

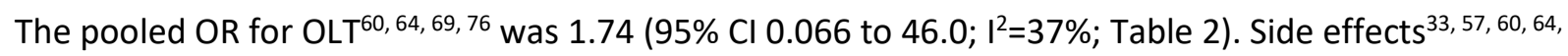
${ }^{68}$ and neurologic deterioration ${ }^{17,33,64,71}$ yielded ORs of 3.28 (95\% Cl 0.542 to $19.9 ; I^{2}=24 \%$; Figure S1, Table 2) and $3.71\left(95 \% \mathrm{Cl} 0.42\right.$ to $32.7 ; I^{2}=10 \%$; Figure S2, Table 2$)$, respectively. The pooled OR of treatment discontinuation ${ }^{17,33,57,60,64,68,69,75,76}$ was 2.96 (95\% Cl 1.14 to $7.66 ; I^{2}=48 \%$; Figure S3, Table 2).

One study found more patients treated with DPen $(6 / 91,6 \%)$ to develop autoimmune diseases as compared to $\mathrm{Zn}(0 / 58)$ or trientine $(0 / 58) \cdot{ }^{73}$ One study detected no difference between DPen- and $\mathrm{Zn}$ treated patients for the 15 -years probability of survival (78 $\pm 6 \%$ vs. $67 \pm 17 \%)$. ${ }^{67}$ Focusing on progression of liver fibrosis, one study found a higher rate of progression in the DPen group $(1 / 14,7 \%)$ compared to $\mathrm{Zn}(0 / 3) .{ }^{70}$ Another study found a higher rate of progression in the $\mathrm{Zn}$ group $(2 / 5,40 \%)$ compared to DPen (0/3). ${ }^{26}$ Extracted outcome data from individual studies are reported in Table S3. 
Sensitivity analyses using the Peto-Method or excluding low quality studies did not fundamentally change the results (Table 2). However, the results from the Peto-Method suggested that DPen may have a higher frequency of side effects, neurologic deterioration, and treatment discontinuation than Zn (Table 2). Subgroup analyses according to the clinical presentations "hepatic" and "(hepatoIneurologic" also did not fundamentally change the results (Table 2). Other sensitivity or subgroup analyses including presymptomatic patients were not possible due to the low number of studies.

\section{Other comparisons}

There were not enough studies comparing other drug combinations to perform meta-analysis. For the comparisons trientine with DPen and trientine with TTM, the authors found no difference in effectiveness in primary outcomes. ${ }^{32,63}$ However, they found early neurologic deterioration to occur more frequently under therapy with trientine $(5 / 16,31 \%$ or $6 / 23,26 \%)$ as compared to DPen $(8 / 97$, $8 \%)^{32}$ or TTM $(1 / 25,4 \%) \cdot{ }^{63}$ At the same time, the relative risk for side effects was found to be lower under trientine therapy $(9 / 38,24 \%$ or $1 / 23,4 \%)$ compared to DPen $(182 / 295,62 \%)^{32}$ or TTM $(7 / 25$, 28\%). ${ }^{63}$ For the comparison between DPen and succimer in the maintenance phase, higher effectiveness $(49 / 60,82 \%$ versus $35 / 60,58 \%)$ and fewer side effects $(9 / 60,15 \%$ versus $22 / 60,37 \%)$ and treatment discontinuations $(11 / 60,18 \%$ versus $25 / 60,42 \%$ ) were reported for succimer (Table S3). ${ }^{58}$

\section{Discussion}

\section{Summary of evidence}

In the present review, we aimed to assess the comparative effectiveness of common WD therapies on patient-relevant outcomes. For the comparison of DPen versus no treatment, we found a strong association between DPen and reduced mortality. Given the commonplace that WD was a fatal disease up until the institution of DPen therapy, this result is merely confirmatory. Although DPen therapy as opposed to no treatment is known to be associated with prevention or remission of clinical symptoms, the corresponding meta-analysis with a prediction interval of 0 to $2.1 \times 10^{15}$ could not confirm the 
clinical experience. This was, however, strongly affected by study heterogeneity and selection bias, as one study included only presymptomatic subjects. ${ }^{55}$

For the comparison of DPen versus $\mathrm{Zn}$, we found no evidence for a difference in mortality, clinical symptoms, OLT, side effects, and neurologic deterioration. For side effects, this lack of evidence could be explained by one outlier study ${ }^{64}$ (Figure S1). In this study, four patients in the $\mathrm{Zn}$ arm with gastrointestinal irritations were counted as events, although two of those four were subsequently switched from Zn-sulphate to Zn-acetate with favorable outcome (see Limitations section for further discussion). Results from sensitivity and subgroup analyses were mostly confirmative, although depending on the analysis used, DPen appeared to have a higher impact on side effects and neurologic deterioration than $\mathrm{Zn}$ - which lines up with previous conclusions. ${ }^{22}$ However, DPen may be associated with more treatment discontinuations than $\mathrm{Zn}$, although data were heterogeneous. We found no indication for subgroup effects in the hepatic and (hepato-)neurologic subgroups. Further inspection of the data suggested that, contrary to $\mathrm{Zn}$, the principal reason for DPen treatment discontinuations may have been the appearance of side effects (Table S3 and data not shown). We emphasize that due to moderate/low study quality and heterogeneity, the results from our meta-analyses should in general be interpreted cautiously and graded as low evidence.

One reason why we may not have detected a difference in effectiveness between DPen and Zn may be due to our decision to restrict analyses to the first treatment block, considering that subsequent treatment blocks are confounded by treatment history. This may also be the reason why our findings deviate from previous conclusions that $\mathrm{Zn}$ is not as effective as chelator therapy. ${ }^{33}$ Another reason may be our choice of analysis: The more conservative beta-binomial meta-analysis but not the Peto-Method resulted in wide confidence intervals crossing the null in most secondary outcomes. Such inconsistency in results across different models reflects once more the considerable clinical and statistical heterogeneity of the included studies. 
During our review of all included studies that compared chelator and $\mathrm{Zn}$ treatments, we noticed that several authors explicitly indicated $\mathrm{Zn}$ as the optimal primary treatment option for certain patient groups including presymptomatic and neurologic patients. Interestingly, several authors' recommendations thus stand in contrast to the recommendations in current guideline publications (recommendations and guideline recommendations in Table S4). During title/abstract screening, we also flagged all single-arm studies that investigated Zn monotherapy. ${ }^{77-84}$ Most of these studies reported positive effects of $Z n$. The present review also indicates $Z n$ to display a favorable safety profile and prevent or relieve symptoms in a similar manner as chelator-therapy would, although results were not definitive. However, $\mathrm{Zn}$ induces copper excretion indirectly via blocking of intestinal copper absorption, which is a slow-acting mechanism that takes a few weeks or months to be effective. ${ }^{10}$ Hence, using only $\mathrm{Zn}$ is not a suitable therapy for patients experiencing acute copper toxicity. A decoppering phase with a chelator applied together with $\mathrm{Zn}$ and followed by $\mathrm{Zn}$ monotherapy, as introduced by Brewer, ${ }^{63}$ may therefore constitute a suitable treatment regimen and form a precedent for future guideline formulation. Alternatively, the non-permanent introduction of a chelator to a patient under long-term $\mathrm{Zn}$ treatment ${ }^{33}$ may prove useful in case of unmitigated copper toxicity.

Recently, a new formulation of TTM called WTX101 was developed and successfully run through a phase 2 trial. ${ }^{14}$ The subsequent phase 3 trial comparing WTX101 with standard of care (chelation or Zn therapy or a combination of both chelation and $\mathrm{Zn}$ therapy) is currently running. ${ }^{15} \mathrm{~A}$ major advantage of WTX101 is the once-daily dosing scheme ${ }^{14}$ (compared to the more complex 2-times a day dosing scheme under DPen ${ }^{19}$ ) which could positively impact on patients' compliance and life-long copper control. In the same vein, efforts have been made to validate a once-daily dosing scheme of trientine for maintenance treatment, ${ }^{85}$ which currently requires a 2 -times dosing scheme. ${ }^{19}$ Similar dosing simplification has unfortunately not yet been achieved for $\mathrm{Zn}$ which requires at least two doses per day to be effective. ${ }^{78}$ However, some pre-work towards an extended-release formulation of $\mathrm{Zn}$ has been published. ${ }^{86}$ 
Conspicuously, only one of the studies included in this review addressed the maintenance phase of WD therapy comparing DPen+Zn to succimer $+Z n .{ }^{58}$ None of the included studies reported on $Z n$ compared to control treatment in the maintenance phase, although $\mathrm{Zn}$ is recommended for maintenance treatment almost throughout all international guidelines (Table S4). During title/abstract screening, we identified some single-arm observational studies that documented the potential suitability of $\mathrm{Zn}$ for maintenance therapy. ${ }^{87-92}$ One reason for the paucity of controlled data on maintenance treatment may be that the field appears to be lacking consensus on the definition of maintenance therapy, i.e. when a patient is "adequately decoppered" ${ }^{20}$

A further interesting observation we made in included studies was concerned with patients with hepatic symptoms. Several study authors reported an apparent lack of correlation between elevated

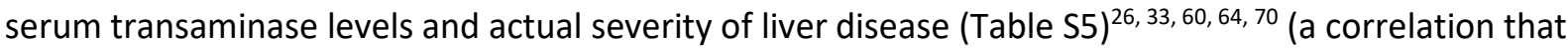
is usually found in the context of liver disease ${ }^{93}$ but may be corrupted in WD due to a predominance of apoptotic over necrotic hepatocyte death ${ }^{94,95}$ ). Yet, within these very studies, the rating of treatment success was often, sometimes even exclusively, based on serum transaminase levels. In light of possible lack of correlation between serum transaminase levels and actual severity of liver disease such rating may in fact be misleading. Alternative liver function tests such as other laboratory values (bilirubin, prothrombin time, ammonia, non-ceruloplasmin bound copper) as well as liver stiffness measurements and histological findings should complement the time course analyses of serum transaminases in WD patients. Currently, there is no consensus on a composite of clinical and biochemical markers of liver function to be used to guide treatment decisions.

\section{Future research}

Future research should consider applying modern methodology such as the combination of randomization and use of routinely collected data. Randomization of the treatment would increase comparability of the groups, reduce selection bias, and facilitate causal conclusions from the study results. As such, the results of the ongoing phase 3 trial comparing WTX101 to other common treatments are highly awaited. ${ }^{15}$ Given the results of this review and the paucity of controlled clinical 
data concerning the maintenance phase of WD treatment, it would be highly desirable though to compare the WTX101 group of maintenance phase patients to a clean Zn group of randomly allocated patients (not to a heterogeneous "standard of care" group). So far, a direct comparison of these two drugs is missing from the literature and clinical decisions concerning the maintenance phase of therapy are hardly supported by evidence.

Further research is also needed to unravel the multifaceted factors that influence serum transaminase levels in WD patients and to delineate a reliable biomarker repertoire for the monitoring of liver function in WD. Likewise, we are still lacking a definitive answer as to which treatment is associated with the lowest risk for early neurologic deterioration (see below), warranting further studies with more precise reporting. And finally, also less common WD drugs such as Chinese herbals ${ }^{28}$ and succimer ${ }^{58}$ could be included in future comparative investigations.

\section{Limitations}

First, the conclusions of our meta-analyses mainly suffer from the fact that high-quality evidence for the comparative effectiveness and safety of WD therapies is scarce. Although DPen and Zn treatment of WD patients has been compared in a fair number of studies, there is not a single randomized controlled trial comparing the two treatments. Moreover, study arms were frequently unbalanced with a bias towards more patients being treated with DPen (Table 1).

Second, all studies but one did not statistically correct for any confounding factors. Some factors seem likely to be confounding factors such as age, clinical presentation, disease stage during diagnosis, or the specialization of the referral center performing the study, i.e. neurologic versus hepatic versus pediatric clinics. The probably most severe limitation, however, comes from selection bias when e.g. study authors would generally prescribe $\mathrm{Zn}$ to presymptomatic patients ${ }^{69}$ or DPen to patients with hepatic symptoms. ${ }^{71}$ We have tried to address some of these limitations by performing sensitivity analyses based on the NOS scores of the studies. 
Third, a common yet very limiting problem we encountered were non-uniform definitions of outcomes. We tried to assess early neurologic deterioration which is often reported as a side effect in response to treatment initiation in WD patients with neurologic presentation. ${ }^{72,96}$ Early neurologic deterioration is thought to occur more frequently in chelator-treated as compared to $\mathrm{Zn}$-treated patients. ${ }^{22}$ In the four studies comparing the effect of DPen versus $\mathrm{Zn}$ on neurologic deterioration, differing or intransparent definitions and time windows were used for the scoring of symptoms. Hence, we meta-analyzed "neurologic deterioration" in general rather than early neurologic deterioration. In light of these limitations, our meta-analysis on neurologic deterioration for the comparison DPen versus $\mathrm{Zn}$ should be interpreted with care. It should further be noted that trientine - while apparently the chelator of choice with respect to side effects in general - appears to confer an overproportionally high risk of early neurologic deterioration. ${ }^{32,63}$ Another example for non-uniform outcome definitions was the scoring of clinical symptoms which was rarely standardized according to published scales. ${ }^{97-99}$ We therefore extracted the binary outcome "asymptomatic/improved" for whenever neurological or liver-related symptoms were reported to be prevented or improved.

Fourth, we did not assess the severity of different side effects. Thus, relatively mild gastrointestinal irritations which are prevalent among Zn-treated patients (data not shown) were scored equally to severe and irreversible autoimmune disorders or nephrotoxicity which are relatively common among DPen-treated patients (data not shown). Accordingly, our meta-analysis on side effects lends conservative support only to the notion that $\mathrm{Zn}$ is safer than DPen.

Fifth, we did not extract dosing regimens of the WD therapies. Our main reason for neglecting this data was that we did not want to conduct further analyses on the already highly biased, low quality studies and risk any chance findings. Hence, we cannot exclude an impact of differing dosing regimens on the effect estimates. 
Sixth, we did not differentiate between the use of different zinc salts such as zinc acetate, zinc sulphate, and zinc gluconate. This is potentially meaningful, as zinc sulfate may cause more gastrointestinal side effects than zinc acetate. ${ }^{64,68,100}$

\section{Conclusions}

There is not enough evidence to claim superiority of one common WD treatment over the other, a firm basis of controlled clinical data is lacking completely. However, there are some indications that $\mathrm{Zn}$ has less side effects and lower treatment discontinuation rate than DPen therapy while being similarly effective. We emphasize that due to low study quality our results should be interpreted cautiously. Future research should focus on higher study quality and reporting.

\section{Acknowledgments}

We thank the authors of the primary studies for their timely and helpful responses to our information requests.

\section{References}

1. Ala A, Walker AP, Ashkan K, Dooley JS, Schilsky ML. Wilson's disease. Lancet 2007; 369(9559): 397-408.

2. Wilson SaK. Progressive lenticular degeneration: a familial nervous disease associated with cirrhosis of the liver. Brain 1912; 34(4): 295-507.

3. Bull PC, Thomas GR, Rommens JM, Forbes JR, Cox DW. The Wilson disease gene is a putative copper transporting P-type ATPase similar to the Menkes gene. Nat Genet 1993; 5(4): 327-37.

4. Boga S, Ala A, Schilsky ML. Hepatic features of Wilson disease. Handb Clin Neurol 2017; 142: 91-99. 
5. Czlonkowska A, Litwin T, Chabik G. Wilson disease: neurologic features. Handb Clin Neurol 2017; 142: 101-19.

6. Walshe JM. Penicillamine, a new oral therapy for Wilson's disease. Am J Med 1956; 21(4): 487-95.

7. Walshe JM. Treatment of Wilson's disease with trientine (triethylene tetramine) dihydrochloride. Lancet 1982; 1(8273): 643-7.

8. Hoogenraad TU, Koevoet R, De Ruyter Korver EGWM. Oral zinc sulphate as long-term treatment in Wilson's disease (hepatolenticular degeneration). Eur Neurol 1979; 18(3): 205-11.

9. Schouwink G. De hepato-cerebrale degeneratie: met een onderzoek van de zinkstofwisseling: Van der Wiel; 1961.

10. Yuzbasiyan-Gurkan V, Grider A, Nostrant T, Cousins RJ, Brewer GJ. Treatment of Wilson's disease with zinc: X. Intestinal metallothionein induction. J Lab Clin Med 1992; 120(3): 380-6.

11. Lee DY, Brewer GJ, Wang Y. Treatment of Wilson's disease with zinc. VII. Protection of the liver from copper toxicity by zinc-induced metallothionein in a rat model. J Lab Clin Med 1989; 114(6): 639-45.

12. Brewer GJ, Dick RD, Yuzbasiyan-Gurkin V, Tankanow R, Young AB, Kluin KJ. Initial therapy of patients with Wilson's disease with tetrathiomolybdate. Arch Neurol 1991; 48(1): 42-7.

13. Klein D, Arora U, Lichtmannegger J, Finckh M, Heinzmann U, Summer KH. Tetrathiomolybdate in the treatment of acute hepatitis in an animal model for Wilson disease. J Hepatol 2004; 40(3): 409-16.

14. Weiss KH, Askari FK, Czlonkowska A, et al. Bis-choline tetrathiomolybdate in patients with Wilson's disease: an open-label, multicentre, phase 2 study. The Lancet Gastroenterology \& Hepatology 2017; 2(12): 869-76.

15. Swenson E. Efficacy and Safety of WTX101 Administered for 48 Weeks Versus Standard of Care in Wilson Disease Subjects. 2018 [cited 2018 October 17]; Available from:

https://clinicaltrials.gov/ct2/show/NCT03403205?cond=wilson+disease\&rank=6 
16. Dziezyc K, Karlinski M, Litwin T, Czlonkowska A. Compliant treatment with anti-copper agents prevents clinically overt Wilson's disease in pre-symptomatic patients. Eur J Neurol 2014; 21(2): 3327.

17. Czlonkowska A, Litwin T, Karlinski M, Dziezyc K, Chabik G, Czerska M. D-penicillamine versus zinc sulfate as first-line therapy for Wilson's disease. Eur J Neurol 2014; 21(4): 599-606.

18. Ferenci P, Czlonkowska A, Stremmel W, et al. EASL Clinical Practice Guidelines: Wilson's disease. J Hepatol 2012; 56(3): 671-85.

19. Roberts EA, Schilsky ML. Diagnosis and treatment of Wilson disease: An update. Hepatology 2008; 47(6): 2089-111.

20. Socha P, Janczyk W, Dhawan A, et al. Wilson's Disease in Children: A Position Paper by the Hepatology Committee of the European Society for Paediatric Gastroenterology, Hepatology and Nutrition. J Pediatr Gastroenterol Nutr 2018; 66(2): 334-44.

21. Nagral A, Sarma MS, Matthai J, et al. Wilson's Disease: Clinical Practice Guidelines of the Indian National Association for Study of the Liver, the Indian Society of Pediatric Gastroenterology, Hepatology and Nutrition, and the Movement Disorders Society of India. Journal of Clinical and Experimental Hepatology 2019; 9(1): 74-98.

22. Wiggelinkhuizen M, Tilanus MEC, Bollen CW, Houwen RHJ. Systematic review: Clinical efficacy of chelator agents and zinc in the initial treatment of Wilson disease. Aliment Pharmacol Ther 2009; 29(9): 947-58.

23. Chen JC, Chuang $\mathrm{CH}$, Wang JD, Wang CW. Combination Therapy Using Chelating Agent and Zinc for Wilson's Disease. Journal of Medical \& Biological Engineering 2015; 35(6): 697-708.

24. Cooper C, Booth A, Britten N, Garside R. A comparison of results of empirical studies of supplementary search techniques and recommendations in review methodology handbooks: a methodological review. Syst Rev 2017; 6(1): 234.

25. Anderson LA, Hakojarvi SL, Boudreaux SK. Zinc acetate treatment in Wilson's disease. Ann Pharmacother 1998; 32(1): 78-87. 
26. Cope-Yokoyama S, Finegold MJ, Sturniolo GC, et al. Wilson disease: histopathological correlations with treatment on follow-up liver biopsies. World J Gastroenterol 2010; 16(12): 1487-94. 27. Mura G, Zimbrean PC, Demelia L, Carta MG. Psychiatric comorbidity in Wilson's disease. Int Rev Psychiatry 2017; 29(5): 445-62.

28. Wang Y, Xie CL, Fu DL, et al. Clinical efficacy and safety of Chinese herbal medicine for Wilson's disease: A systematic review of 9 randomized controlled trials. Complement Ther Med 2012; 20(3): 143-54.

29. Carta MG, Mura G, Sorbello O, Farina G, Demelia L. Quality of life and psychiatric symptoms in wilson's disease: The relevance of bipolar disorders. Clin Pract Epidemiol Ment Health 2012; 8: 102-09.

30. Taylor RM, Chen Y, Dhawan A. Triethylene tetramine dihydrochloride (trientine) in children with Wilson disease: experience at King's College Hospital and review of the literature. Eur J Pediatr 2009; 168(9): 1061-68.

31. Aggarwal A, Bhatt M. Advances in treatment of Wilson disease. Tremor and Other Hyperkinetic Movements 2018; 8: 1-13.

32. Weiss KH, Thurik F, Gotthardt DN, et al. Efficacy and safety of oral chelators in treatment of patients with wilson disease. Clin Gastroenterol Hepatol 2013; 11(8): 1028-35.

33. Weiss KH, Gotthardt DN, Klemm D, et al. Zinc monotherapy is not as effective as chelating agents in treatment of Wilson disease. Gastroenterology 2011; 140(4): 1189-98.

34. Wells GA, Shea B, O'connell D, et al. The Newcastle-Ottawa Scale (NOS) for assessing the quality of nonrandomised studies in meta-analyses. 2014 [cited 2018 May 29]; Available from: http://www.ohri.ca/programs/clinical epidemiology/oxford.asp

35. Higgins JPT, Sterne JaC, Savović J, et al. A revised tool for assessing risk of bias in randomized trials In: Chandler J, McKenzie J, Boutron I, Welch V (editors). Cochrane Methods. Cochrane Database of Systematic Reviews 2016(10): (Suppl 1). 
36. Mathes T, Kuss O. A comparison of methods for meta-analysis of a small number of studies with binary outcomes. Research synthesis methods 2018; 9(3): 366-81.

37. Bender R, Friede T, Koch A, et al. Methods for evidence synthesis in the case of very few studies. Research synthesis methods 2018; 9(3): 382-92.

38. Veroniki AA, Jackson D, Bender R, et al. Methods to calculate uncertainty in the estimated overall effect size from a random-effects meta-analysis. Research synthesis methods 2018.

39. Veroniki AA, Jackson D, Viechtbauer W, et al. Methods to estimate the between-study variance and its uncertainty in meta-analysis. Research synthesis methods 2016; 7(1): 55-79.

40. Kuss O. Statistical methods for meta-analyses including information from studies without any events-add nothing to nothing and succeed nevertheless. Stat Med 2015; 34(7): 1097-116.

41. Sharma T, Gøtzsche PC, Kuss O. The Yusuf-Peto method was not a robust method for metaanalyses of rare events data from antidepressant trials. J Clin Epidemiol 2017; 91: 129-36.

42. Higgins JPT, Thompson SG, Deeks JJ, Altman DG. Measuring inconsistency in meta-analyses. BMJ (Clinical research ed) 2003; 327(7414): 557-60.

43. Inthout J, loannidis JPA, Rovers MM, Goeman JJ. Plea for routinely presenting prediction intervals in meta-analysis. BMJ Open 2016; 6(7).

44. Yildiz Kabak V, Calders P, Duger T, Mohammed J, Van Breda E. Short and long-term impairments of cardiopulmonary fitness level in previous childhood cancer cases: a systematic review. Support Care Cancer 2018.

45. Schwarzer G. meta: General Package for Meta-Analysis. 2018 [cited 2018 October 23]; Available from: https://CRAN.R-project.org/package=meta

46. Xie XW, Li T. [Follow-up study on the therapeutic efficacy in 80 children with Wilson disease]. Zhongguo Dangdai Erke Zazhi 2010; 12(5): 398-400.

47. Tabel Y, Selimoglu MA, Varol FI, Elmas AT, Gungor S, Karabiber H. Evaluation of renal function in children with wilson's disease. [Turkish]. Guncel Pediatri 2017; 15(1): 6-11. 
48. Hu Z, Hu C, Liu Z. Clinical analysis and short-term effect of hepatolenticular degeneration. [Chinese]. Acta Academiae Medicinae Hubei 1996; 17(3): 291-93.

49. Li N, Yao J, Lu C, Xia B, Chen X. A comparison of efficacy and urinary copper excretion in the treatment of hepatolenticular degeneration with penicillamine and zinc. [Chinese]. Acta Academiae Medicinae Shanghai 1996; 23(5): 343-46.

50. Szleper M, Rodo M, Pilkowska E, Czlonkowska A. Results of the treatment of Wilson's disease with zinc sulfate and d-penicillamine. [Polish]. Polski tygodnik lekarski (Warsaw, Poland : 1960) 1992; 47(20-21): 456-58.

51. Chen ZR. Early diagnosis and treatment of hepatolenticular degeneration: clinical analysis of 92 cases. [Chinese]. Zhonghua shen jing jing shen ke za zhi = Chinese journal of neurology and psychiatry 1985; 18(4): 226-28.

52. Chen JL, Wang DH. Clinical study on improvement of liver function and liver cirrhosis in hepatolenticular degeneration patients treated with Shugantidanpaidu Decoction. New J Tradit Chen Med 2008; 40: 28-29.

53. Chen JL, Wang DH. Clinical observation on treatment of 59 cases of hepatolenticular degeneration patients with chaihuanggandou pulvis. J Sichuan Tradit Chin Med 2010; 28: 72-74.

54. Goldstein NP, Tauxe WN, Mccall JT, Randall RV, Gross JB. What Wilson's disease and its treatment have taught us about the metabolism of copper. Observations in 27 cases. Med Clin North Am 1968; 52(4): 989-1001.

55. Sternlieb I, Scheinberg IH. Prevention of Wilson's disease in asymptomatic patients. N Engl J Med 1968; 278(7): 352-9.

56. Strickland GT, Frommer D, Leu ML, Pollard R, Sherlock S, Cumings JN. Wilson's disease in the United Kingdom and Taiwan. I. General characteristics of 142 cases and prognosis. II. A genetic analysis of 88 cases. Q J Med 1973; 42(167): 619-38.

57. Czlonkowska A, Gajda J, Rodo M. Effects of long-term treatment in Wilson's disease with Dpenicillamine and zinc sulphate. J Neurol 1996; 243(3): 269-73. 
58. Ren MS, Zhang Z, Wu JX, Li F, Xue BC, Yang RM. Comparison of long lasting therapeutic effects between succimer and penicillamine on hepatolenticular degeneration. World J Gastroenterol 1998; 4(6): 530-32.

59. Durand F, Bernuau J, Giostra E, et al. Wilson's disease with severe hepatic insufficiency: beneficial effects of early administration of D-penicillamine. Gut 2001; 48(6): 849-52.

60. Iorio R, D'ambrosi M, Marcellini M, et al. Serum transaminases in children with Wilson's disease. J Pediatr Gastroenterol Nutr 2004; 39(4): 331-36.

61. Kumagi T, Horiike N, Michitaka K, et al. Recent clinical features of Wilson's disease with hepatic presentation. J Gastroenterol 2004; 39(12): 1165-9.

62. Czlonkowska A, Tarnacka B, Litwin T, Gajda J, Rodo M. Wilson's disease-cause of mortality in 164 patients during 1992-2003 observation period. J Neurol 2005; 252(6): 698-703.

63. Brewer GJ, Askari F, Lorincz MT, et al. Treatment of Wilson disease with ammonium tetrathiomolybdate - IV. Comparison of tetrathiomolybdate and trientine in a double-blind study of treatment of the neurologic presentation of Wilson disease. Arch Neurol 2006; 63(4): 521-27.

64. Medici V, Trevisan CP, D'inca R, et al. Diagnosis and management of Wilson's disease: results of a single center experience. J Clin Gastroenterol 2006; 40(10): 936-41.

65. Merle U, Schaefer M, Ferenci P, Stremmel W. Clinical presentation, diagnosis and long-term outcome of Wilson's disease: a cohort study. Gut 2007; 56(1): 115-20.

66. Brewer GJ, Askari F, Lorincz MT, et al. Tetrathiomolybdate versus trientine in the initial treatment of neurologic Wilson's disease. Progress in Neurotherapeutics and Neuropsychopharmacology 2008; 3(1): 153-65.

67. Svetel M, Pekmezovic T, Petrovic I, et al. Long-term outcome in Serbian patients with Wilson disease. Eur J Neurol 2009; 16(7): 852-7.

68. Bruha R, Marecek Z, Pospisilova L, et al. Long-term follow-up of Wilson disease: natural history, treatment, mutations analysis and phenotypic correlation. Liver International 2011; 31(1): 83-91. 
69. Rodriguez B, Burguera J, Berenguer M. Response to different therapeutic approaches in Wilson disease. A long-term follow up study. Ann Hepatol 2012; 11(6): 907-14.

70. Sini M, Sorbello O, Sanna F, et al. Histologic evolution and long-term outcome of Wilson's disease: results of a single-center experience. Eur J Gastroenterol Hepatol 2013; 25(1): 111-7.

71. Ranucci G, Di Dato F, Spagnuolo MI, Vajro P, lorio R. Zinc monotherapy is effective in Wilson's disease patients with mild liver disease diagnosed in childhood: a retrospective study. Orphanet J Rare Dis 2014; 9: 41.

72. Litwin T, Dziezyc K, Karlinski M, Chabik G, Czepiel W, Czlonkowska A. Early neurological worsening in patients with Wilson's disease. J Neurol Sci 2015; 355(1-2): 162-7.

73. Seessle J, Gotthardt DN, Schafer M, et al. Concomitant immune-related events in Wilson disease: implications for monitoring chelator therapy. J Inherit Metab Dis 2016; 39(1): 125-30. 74. Mathes T, Pieper D. Clarifying the distinction between case series and cohort studies in systematic reviews of comparative studies: potential impact on body of evidence and workload. BMC Med Res Methodol 2017; 17(1): 107.

75. Tai CS, Wu JF, Chen HL, Hsu HY, Chang MH, Ni YH. Modality of treatment and potential outcome of Wilson disease in Taiwan: A population-based longitudinal study. J Formos Med Assoc 2018; 117(5): 421-26.

76. Vieira Barbosa J, Fraga M, Saldarriaga J, et al. Hepatic manifestations of Wilson's disease: 12year experience in a Swiss tertiary referral centre. Swiss Med Wkly 2018; 148: w14699.

77. Abuduxikuer K, Wang JS. Zinc mono-therapy in pre-symptomatic chinese children with Wilson Disease: A single center, retrospective study. PLoS One 2014; 9(1): e86168.

78. Brewer GJ, Dick RD, Johnson VD, Brunberg JA, Kluin KJ, Fink JK. Treatment of Wilson's disease with zinc: XV long-term follow-up studies. J Lab Clin Med 1998; 132(4): 264-78.

79. Cacic M, Percl M, Jadresin O, Kolacek S. Zinc as initial treatment of Wilson's disease in children. [Serbian]. Lijec Vjesn 2000; 122(3-4): 77-81. 
80. Eda K, Mizuochi T, Iwama I, et al. Zinc monotherapy for young children with presymptomatic Wilson disease: a multicenter study in Japan. J Gastroenterol Hepatol 2018; 33(1): 264-69.

81. Linn FHH, Houwen RHJ, Van Hattum J, Van Der Kleij S, Van Erpecum KJ. Long-term exclusive zinc monotherapy in symptomatic Wilson disease: Experience in 17 patients. Hepatology 2009; 50(5): $1442-52$.

82. Marcellini M, Di Ciommo V, Callea F, et al. Treatment of Wilson's disease with zinc from the time of diagnosis in pediatric patients: A single-hospital, 10-year follow-up study. J Lab Clin Med 2005; 145(3): 139-43.

83. Wu ZY, Lin MT, Murong SX, Wang N. Molecular diagnosis and prophylactic therapy for presymptomatic Chinese patients with Wilson disease. Arch Neurol 2003; 60(5): 737-41.

84. Gupta P, Choksi M, Goel A, et al. Maintenance zinc therapy after initial penicillamine chelation to treat symptomatic hepatic Wilson's disease in resource constrained setting. Indian J Gastroenterol 2018; 37(1): 31-38.

85. Ala A, Aliu E, Schilsky ML. Prospective pilot study of a single daily dosage of trientine for the treatment of Wilson disease. Dig Dis Sci 2015; 60(5): 1433-9.

86. Nagy J, Folhoffer A, Horvath A, et al. Kinetic study of zinc sulphate release from lipophilic matrices prepared for the therapy of Wilson's disease. Pharmazie 2005; 60(7): 524-6.

87. Wang LC, Wang JD, Tsai CR, Cheng SB, Lin CC. Clinical features and therapeutic response in Taiwanese children with Wilson's disease: 12 years of experience in a single center. Pediatr Neonatol 2010; 51(2): 124-9.

88. Sinha S, Taly AB. Withdrawal of penicillamine from zinc sulphate-penicillamine maintenance therapy in Wilson's disease: promising, safe and cheap. J Neurol Sci 2008; 264(1-2): 129-32.

89. Arnon R, Calderon JF, Schilsky M, Emre S, Shneider BL. Wilson disease in children: serum aminotransferases and urinary copper on triethylene tetramine dihydrochloride (trientine) treatment. J Pediatr Gastroenterol Nutr 2007; 44(5): 596-602. 
90. Jablonska-Kaszewska I, Drobinska-Jurowiecka A, Dabrowska E, Trocha H. Results of treatment of Wilson's disease--own observations. Med Sci Monit 2003; 9 Suppl 3: 9-14.

91. Hoogenraad TU, Van Hattum J, Van Den Hamer CJ. Management of Wilson's disease with zinc sulphate. Experience in a series of 27 patients. J Neurol Sci 1987; 77(2-3): 137-46.

92. Van Caillie-Bertrand M, Degenhart HJ, Visser HKA. Oral zinc sulphate for Wilson's disease. Arch Dis Child 1985; 60(7): 656-59.

93. Bonder A, Tapper EB, Afdhal NH. Contemporary assessment of hepatic fibrosis. Clin Liver Dis 2015; 19(1): 123-34.

94. Lang PA, Schenck M, Nicolay JP, et al. Liver cell death and anemia in Wilson disease involve acid sphingomyelinase and ceramide. Nat Med 2007; 13: 164.

95. Woolbright BL, Antoine DJ, Jenkins RE, Bajt ML, Park BK, Jaeschke H. Plasma biomarkers of liver injury and inflammation demonstrate a lack of apoptosis during obstructive cholestasis in mice. Toxicol Appl Pharmacol 2013; 273(3): 524-31.

96. Brewer GJ, Terry CA, Aisen AM, Hill GM. Worsening of neurologic syndrome in patients with Wilson's disease with initial penicillamine therapy. Arch Neurol 1987; 44(5): 490-3.

97. Czlonkowska A, Tarnacka B, Moller JC, et al. Unified Wilson's Disease Rating Scale - A proposal for the neurological scoring of Wilson's disease patients. Neurol Neurochir Pol 2007; 41(1): $1-12$.

98. Ferenci P, Caca K, Loudianos G, et al. Diagnosis and phenotypic classification of Wilson disease. Liver international : official journal of the International Association for the Study of the Liver 2003; 23(3): 139-42.

99. Aggarwal A, Aggarwal N, Nagral A, Jankharia G, Bhatt M. A novel Global Assessment Scale for Wilson's Disease (GAS for WD). Mov Disord 2009; 24(4): 509-18.

100. Wiernicka A, Janczyk W, Dadalski M, Avsar Y, Schmidt H, Socha P. Gastrointestinal side effects in children with Wilson's disease treated with zinc sulphate. World J Gastroenterol 2013; 19(27):

4356-62. 


\section{Tables}

\section{Table 1: Characteristics of included studies: Overview}

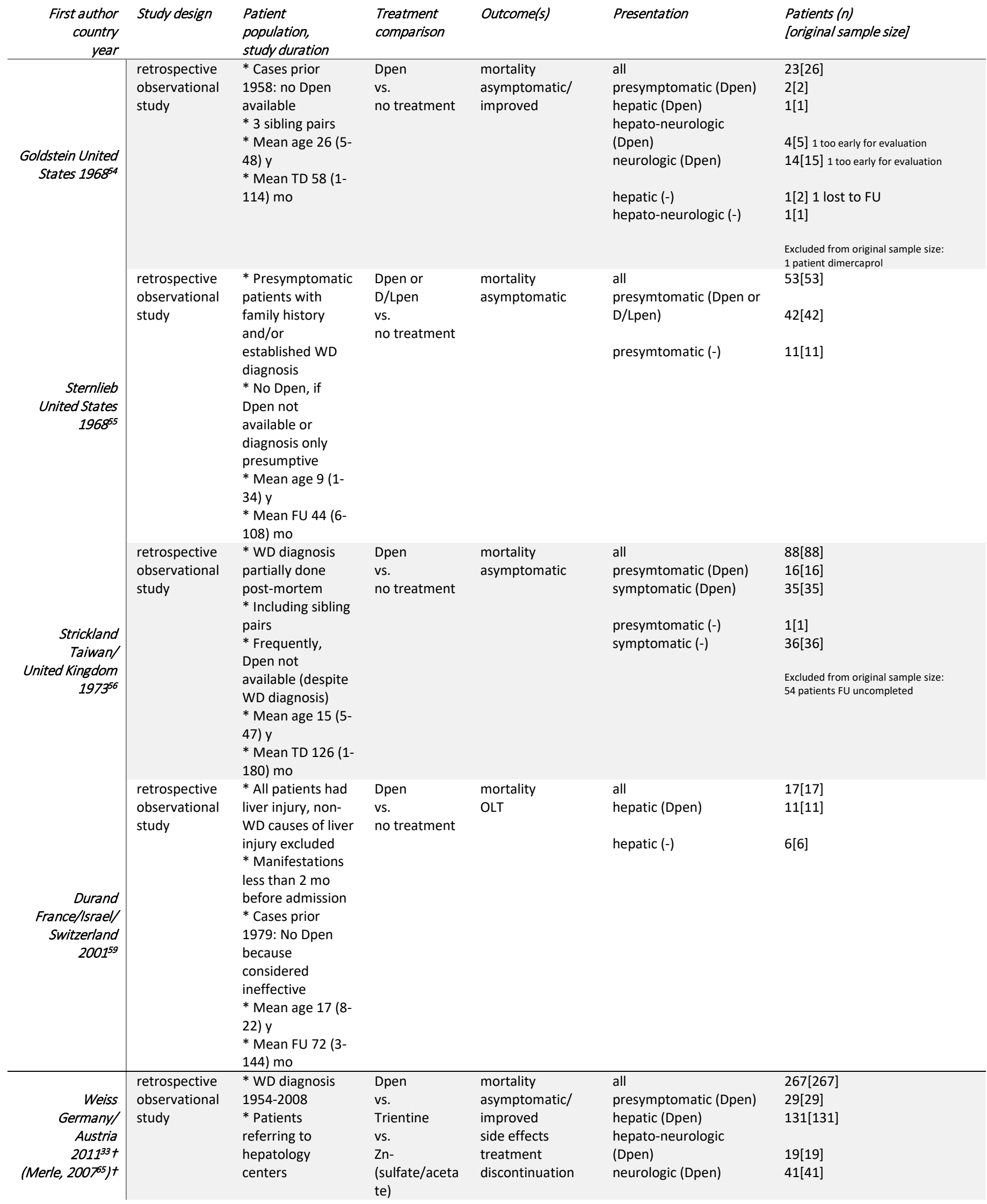




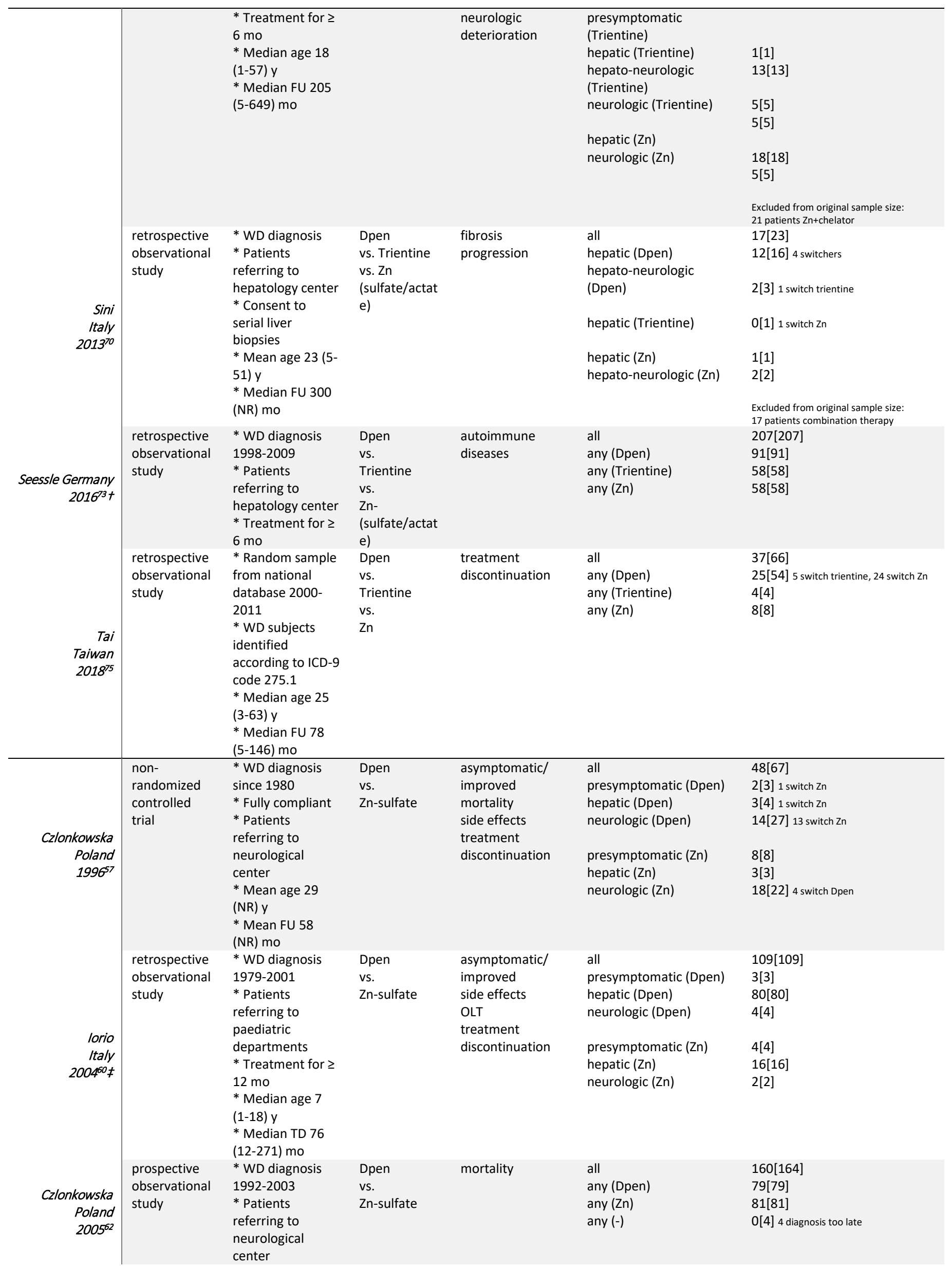




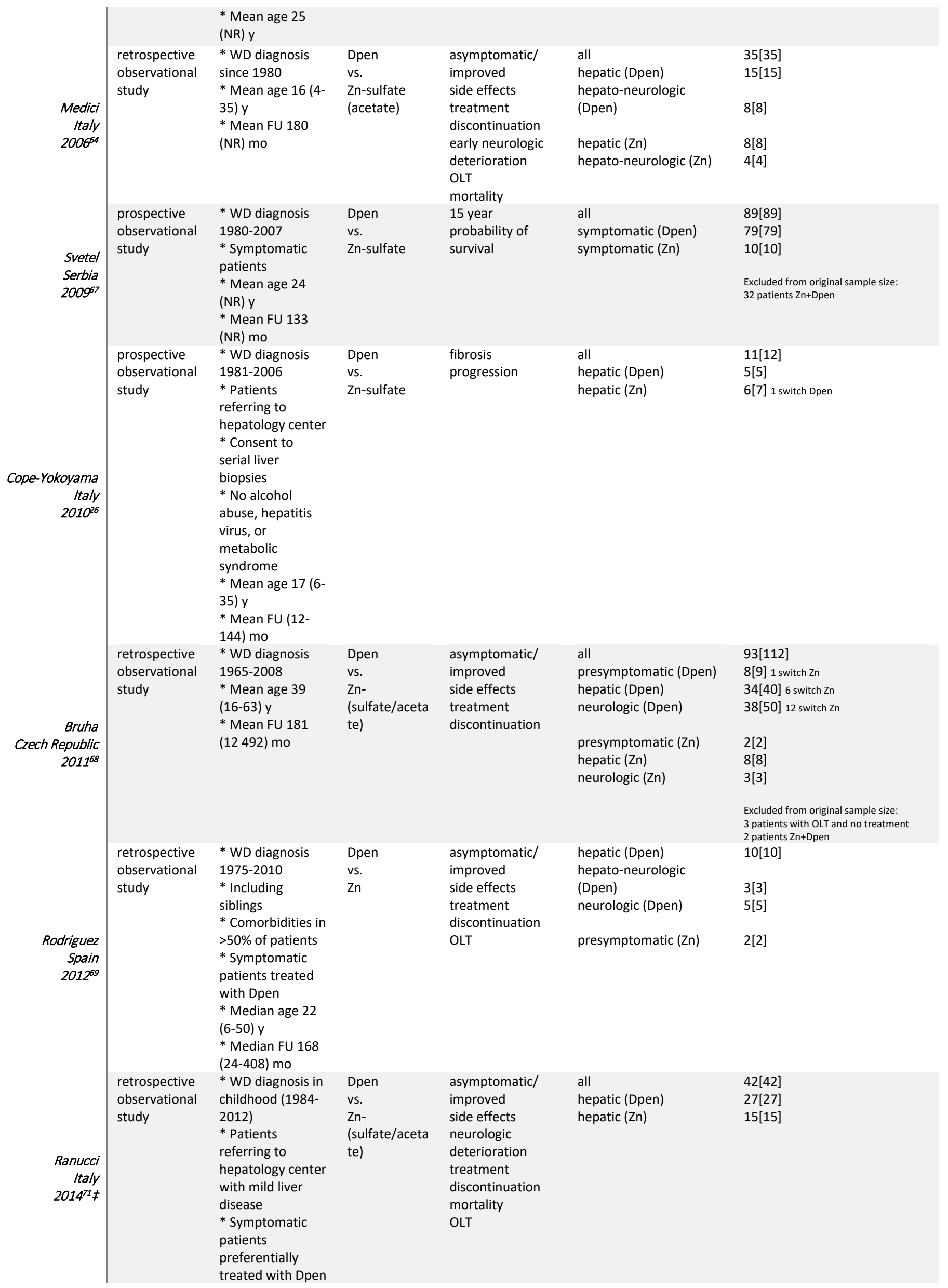




\begin{tabular}{|c|c|c|c|c|c|c|}
\hline & & $\begin{array}{l}\text { * Treatment for } \geq \\
6 \text { mo } \\
* \text { Median age } 6 \\
(1-16) \text { y } \\
\text { * Median FU } 144 \\
(19-302) \text { mo }\end{array}$ & & & & \\
\hline $\begin{array}{r}\text { Czlonkowska } \\
\text { Poland } \\
2014^{17} \\
\text { (Litwin, 201572) }\end{array}$ & $\begin{array}{l}\text { retrospective } \\
\text { observational } \\
\text { study }\end{array}$ & $\begin{array}{l}\text { * WD diagnosis in } \\
\text { adulthood (2005- } \\
2009 \text { ) } \\
\text { * Patients } \\
\text { referring to } \\
\text { neurological } \\
\text { center } \\
\text { * Symptomatic } \\
\text { patients } \\
\text { * Median age 22- } \\
33 \text { (NR) y } \\
\text { * Median FU } 48 \\
\text { (NR) mo }\end{array}$ & $\begin{array}{l}\text { Dpen } \\
\text { vs. } \\
\text { Zn-sulfate }\end{array}$ & $\begin{array}{l}\text { asymptomatic/ } \\
\text { improved } \\
\text { side effects } \\
\text { treatment } \\
\text { discontinuation } \\
\text { mortality } \\
\text { early neurologic } \\
\text { deterioration }\end{array}$ & $\begin{array}{l}\text { all } \\
\text { hepatic (Dpen) } \\
\text { neurologic (Dpen) } \\
\text { hepatic (Zn) } \\
\text { neurologic (Zn) }\end{array}$ & $\begin{array}{l}143[143] \\
36[36] \\
35[35] \\
\\
51[51] \\
21[21]\end{array}$ \\
\hline $\begin{array}{r}\text { Vieira Barbosa } \\
\text { Switzerland } \\
2018^{76}\end{array}$ & $\begin{array}{l}\text { retrospective } \\
\text { observational } \\
\text { study }\end{array}$ & $\begin{array}{l}\text { * WD diagnosis in } \\
\text { adulthood (2004- } \\
2016) \\
\text { * Patients } \\
\text { referring to } \\
\text { hepatology center } \\
\text { * Symptomatic } \\
\text { patients } \\
\text { * Median age } 26 \\
(18-56) \text { y } \\
\end{array}$ & $\begin{array}{l}\text { Dpen } \\
\text { vs. } \\
\text { Zn-acetate }\end{array}$ & $\begin{array}{l}\text { Treatment } \\
\text { discontinuation } \\
\text { mortality } \\
\text { OLT }\end{array}$ & $\begin{array}{l}\text { all } \\
\text { hepatic (Dpen) } \\
\text { hepatic (Zn) }\end{array}$ & $\begin{array}{l}3[8] \\
3[6] 3 \text { switch trientine } \\
0[2] 2 \text { switch Dpen } \\
\text { Excluded from original sample size: } \\
2 \text { patients with OLT and no treatment }\end{array}$ \\
\hline $\begin{array}{r}\text { Kumagi } \\
\text { Japan } \\
2004^{61}\end{array}$ & $\begin{array}{l}\text { retrospective } \\
\text { observational } \\
\text { study }\end{array}$ & $\begin{array}{l}\text { * WD diagnosis } \\
1976-2003 \\
\text { * All patients } \\
\text { showed hepatic } \\
\text { manifestations } \\
\text { * No hepatitis } \\
\text { virus in most } \\
\text { patients } \\
\text { * } 4 \text { cases with } \\
\text { family history and } \\
4 \text { siblings } \\
\text { * Mean age } 32 \text { (9- } \\
\text { 66) y } \\
\text { * Median FU } 48 \\
\text { (1-180) mo }\end{array}$ & $\begin{array}{l}\text { Dpen } \\
\text { vs. } \\
\text { Trientine }\end{array}$ & $\begin{array}{l}\text { mortality } \\
\text { OLT } \\
\text { side effects } \\
\text { treatment } \\
\text { discontinuation }\end{array}$ & $\begin{array}{l}\text { all } \\
\text { presymptomatic (Dpen) } \\
\text { hepatic (Dpen) } \\
\text { hepato-neurologic } \\
\text { (Dpen) } \\
\text { hepatic (T) }\end{array}$ & $\begin{array}{l}13[16] \\
1[1] \\
10[10] \\
4[4] \\
1[1]\end{array}$ \\
\hline $\begin{array}{r}\text { Weiss } \\
\text { Germany/ } \\
\text { Austria/ } \\
\text { Eurowilson, } \\
2013^{32+}\end{array}$ & $\begin{array}{l}\text { retrospective } \\
\text { observational } \\
\text { study }\end{array}$ & $\begin{array}{l}\text { * WD diagnosis } \\
1956-2010 \\
\text { * Patients } \\
\text { referring to } \\
\text { tertiary care } \\
\text { centers or under } \\
\text { trientine } \\
\text { monotherapy } \\
\text { from } \\
\text { EUROWILSON } \\
\text { registry } \\
\text { * Treatment for } \geq \\
6 \text { mo } \\
{ }^{*} \text { Median age } 18 \\
\text { (1-60) y } \\
{ }^{*} \text { Median FU } 160 \\
\text { (NR) mo }\end{array}$ & $\begin{array}{l}\text { Dpen } \\
\text { vs. } \\
\text { Trientine }\end{array}$ & $\begin{array}{l}\text { asymptomatic/ } \\
\text { improved } \\
\text { side effects } \\
\text { treatment } \\
\text { discontinuation } \\
\text { early neurologic } \\
\text { deterioration }\end{array}$ & $\begin{array}{l}\text { all } \\
\text { presymptomatic (Dpen) } \\
\text { hepatic (Dpen) } \\
\text { hepato-neurologic } \\
\text { (Dpen) } \\
\text { neurologic (Dpen) } \\
\text { presymptomatic } \\
\text { (trientine) } \\
\text { hepatic (trientine) } \\
\text { hepato-neurologic } \\
\text { (trientine) } \\
\text { neurologic (trientine) }\end{array}$ & $\begin{array}{l}333[333] \\
48[48] \\
150[150] \\
31[31] \\
66[66] \\
2[2] \\
20[20] \\
7[7] \\
9[9] \\
\text { Excluded from original sample size: } \\
72 \text { first-line treatments other than Dpen } \\
\text { or trientine }\end{array}$ \\
\hline $\begin{array}{r}\text { Ren } \\
\text { China } \\
1998^{58}\end{array}$ & $\begin{array}{l}\text { non- } \\
\text { randomized } \\
\text { controlled } \\
\text { trial }\end{array}$ & $\begin{array}{l}\text { *WD diagnosis } \\
1994-1997 \\
* \text { Trial on } \\
\text { maintenance } \\
\text { treatment } \\
\text { (patients initially } \\
\text { treated with } \\
\text { unithiol or EDTA) } \\
\text { * Mean age 19 } \\
\text { (NR) y } \\
\end{array}$ & $\begin{array}{l}\text { Dpen+Zn- } \\
\text { gluconate } \\
\text { vs. } \\
\text { Succimer+Zn- } \\
\text { gluconate }\end{array}$ & $\begin{array}{l}\text { asymptomatic/ } \\
\text { improved } \\
\text { side effects } \\
\text { treatment } \\
\text { discontinuation }\end{array}$ & $\begin{array}{l}\text { all } \\
\text { presymptomatic (Dpen) } \\
\text { hepatic (Dpen) } \\
\text { neurologic (Dpen) } \\
\text { presymptomatic } \\
\text { (Succimer) } \\
\text { hepatic (Succimer) } \\
\text { neurologic (Succimer) }\end{array}$ & $\begin{array}{l}120[120] \\
10[10] \\
9[9] \\
41[41] \\
\\
10[10] \\
10[10] \\
40[40]\end{array}$ \\
\hline
\end{tabular}




\begin{tabular}{|c|c|c|c|c|c|c|}
\hline & & $\begin{array}{l}\text { * Mean FU } 18 \text { (6- } \\
\text { 36) mo }\end{array}$ & & & & \\
\hline $\begin{array}{r} \\
\text { Brewer } \\
\text { United States/ } \\
\text { Canada } \\
2006^{63} \\
\text { (Brewer, 200866) }\end{array}$ & $\begin{array}{l}\text { randomized } \\
\text { controlled } \\
\text { trial }\end{array}$ & $\begin{array}{l}\text { * Start of } \\
\text { enrollment } 1994 \\
\text { * Symptomatic } \\
\text { patients } \\
\text { * Treatment- } \\
\text { naive or chelator } \\
\text { treatment for < } \\
28 \text { d or long-term } \\
\text { treatment } \\
\text { stopped for > } 1 \text { y } \\
\text { with development } \\
\text { of new symptoms } \\
\text { * Trial on initial } \\
\text { treatment } \\
\text { (patients } \\
\text { subsequently } \\
\text { treated with } \mathrm{Zn}- \\
\text { acetate for } \\
\text { maintenance) } \\
\text { * Mean age } 28 \\
\text { (13-49) y } \\
\text { * TD } 2 \text { mo }\end{array}$ & $\begin{array}{l}\text { Trientine+Zn- } \\
\text { acetate } \\
\text { vs. TTM+Zn- } \\
\text { acetate }\end{array}$ & $\begin{array}{l}\text { early neurologic } \\
\text { deterioration } \\
\text { mortality } \\
\text { side effects }\end{array}$ & $\begin{array}{l}\text { all } \\
\text { neurologic (Trientine) } \\
\text { neurologic (TTM) }\end{array}$ & $\begin{array}{l}48[48] \\
23[23] \\
25[25]\end{array}$ \\
\hline
\end{tabular}

† likely cohort overlap (Heidelberg University Hospital)

¥ likely cohort overlap (University of Naples)

Age, age at admission; DPen, D-penicillamine; d, days; EDTA, ethylenediaminetetraacetic acid; FU, follow-up; mo, months; NR, not reported; OLT, orthotopic liver transplantation; TD, treatment duration; TTM, tetrathiomolybdate; WD, Wilson's disease; $y$, years; $Z n$, zinc salts. 


\section{Table 2: Summary of results}

\begin{tabular}{|c|c|c|c|c|c|c|c|}
\hline Outcome & \# studies & \# patients & Method & $\begin{array}{l}\text { Effect estimate } \\
\text { (OR) }\end{array}$ & $95 \% \mathrm{Cl}$ & $P^{2}(\%)$ & $\begin{array}{l}\text { Prediction } \\
\text { interval }\end{array}$ \\
\hline \multicolumn{8}{|c|}{ D-Penicillamine versus no treatment } \\
\hline \multirow{2}{*}{ Mortality } & \multirow{2}{*}{4} & \multirow{2}{*}{125 versus 52} & BBIN & 0.013 & 0.0010 to 0.17 & \multirow{2}{*}{31} & \multirow{2}{*}{0 to 0.53} \\
\hline & & & Peto & 0.02 & 0.01 to 0.05 & & \\
\hline \multirow{2}{*}{ Asymptomatic } & \multirow{2}{*}{3} & \multirow{2}{*}{114 versus 50} & BBIN & 22.3 & 0.40 to $1.2 \times 10^{3}$ & \multirow{2}{*}{86} & \multirow{2}{*}{0 to $2.1 \times 10^{15}$} \\
\hline & & & Peto & NA & NA & & \\
\hline \multicolumn{8}{|l|}{ D-Penicillamine versus zinc salts } \\
\hline \multirow{2}{*}{ Mortality } & \multirow{2}{*}{7} & \multirow{2}{*}{460 versus 238} & BBIN & 0.73 & 0.16 to 3.40 & \multirow{2}{*}{37} & \multirow{2}{*}{0.01 to 71.46} \\
\hline & & & Peto & 1.14 & 0.55 to 2.33 & & \\
\hline Asymptomatic/improved & 7 & 518 versus 173 & PM-HK & 0.84 & 0.48 to 1.48 & 0 & NA \\
\hline Asymptomatic/improved (sensitivityt) & 5 & 280 versus 148 & PM-HK & 0.96 & 0.43 to 2.14 & 12 & 0.31 to 2.98 \\
\hline \multirow{2}{*}{$\begin{array}{l}\text { Asymptomatic/improved } \\
\text { (subgroup: hepatic) }\end{array}$} & \multirow{2}{*}{5} & \multirow{2}{*}{243 versus 100} & BBIN & 0.59 & 0.16 to 2.14 & \multirow{2}{*}{0} & \multirow{2}{*}{ NA } \\
\hline & & & Peto & 0.65 & 0.34 to 1.25 & & \\
\hline \multirow{2}{*}{$\begin{array}{l}\text { Asymptomatic/improved } \\
\text { [subgroup: (hepato-)neurologic] }\end{array}$} & \multirow{2}{*}{4} & \multirow{2}{*}{141 versus 43} & BBIN & 0.79 & 0.15 to 4.14 & \multirow{2}{*}{0} & \multirow{2}{*}{ NA } \\
\hline & & & Peto & 0.99 & 0.40 to 2.46 & & \\
\hline \multirow{2}{*}{ OLT } & \multirow{2}{*}{4} & \multirow{2}{*}{134 versus 38} & BBIN & 1.74 & 0.066 to 46.0 & \multirow{2}{*}{37} & \multirow{2}{*}{0 to 502.6} \\
\hline & & & Peto & 0.68 & 0.13 to 3.40 & & \\
\hline Side effects & 5 & 463 versus 103 & BBIN & 3.28 & 0.54 to 19.9 & 24 & 064 to 1928 \\
\hline side ellects & 3 & 403 versus 103 & Peto & 3.68 & 2.10 to 6.43 & 24 & 0.041019 .20 \\
\hline Neurologic deterioration & 4 & 130 versus 45 & BBIN & 3.71 & 0.42 to 32.7 & 10 & 0.22 to 40.02 \\
\hline & & & Peto & 2.86 & 1.18 to 6.93 & & \\
\hline Treatment discontinuation & 9 & 612 versus 187 & PM-HK & 2.96 & 1.14 to 7.66 & 48 & 0.31 to 27.89 \\
\hline Treatment discontinuation (sensitivity + ) & 6 & 368 versus 160 & PM-HK & 3.62 & 1.05 to 12.51 & 57 & 0.41 to 26.13 \\
\hline Treatment discontinuation & 6 & 255 versus 102 & BBIN & 2.55 & 0.66 to 9.93 & 44 & 026 to 2904 \\
\hline (subgroup: hepatic) & 0 & zos veisus dove & Peto & 2.82 & 1.60 to 4.98 & 44 & 0.201023 .04 \\
\hline Treatment discontinuation & 4 & 153 versus 33 & BBIN & 4.49 & 0.42 to 48.0 & 70 & 0 to $8.7 \times 10^{3}$ \\
\hline [subgroup: (hepato-)neurologic] & 4 & 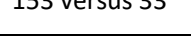 & Peto & NA & NA & 10 & $000.1 \times 10$ \\
\hline
\end{tabular}

† sensitivity analysis for studies rated NOS $\geq 6$; primary outcomes shown in bold, secondary outcomes in non-bold characters

BBIN, Beta-binomial model; Cl, confidence interval; NA, not applicable; NOS, Newcastle-Ottawa scale; OR, odds ratio; Peto, Yusuf-Peto method; PM-HK, Paule-Mandel estimator with modified Hartung-Knapp confidence intervals

Note: We used PM-HK whenever there were at least 6 studies to pool or for sensitivity analyses of PM-HK analyses, we used BBIN whenever there were outcomes with 0 events or less than 6 studies. We did not use Peto when $I^{2}$ was $>50 \%$. We did not calculate prediction intervals when $\mathrm{I}^{2}$ was $0 \%$. 


\section{Figure legends}

Figure 1: Study flow diagram for the selection of studies.

Figure 2: Meta-analysis of DPen versus no treatment. Effect of DPen versus no treatment on all-cause mortality. Summary odds ratio derived from beta-binomial model (BBIN); box sizes reflect the weights of the fixed-effect inverse variance model (IV).

Figure 3: Meta-analyses of DPen versus Zn treatment. (A) Effect of DPen versus Zn treatment on allcause mortality. Summary odds ratio derived from beta-binomial model (BBIN); box sizes reflect the weights of the fixed-effect inverse variance model (IV). (B) Effect of DPen versus Zn treatment on prevention, remission, or amelioration of clinical symptoms (asymptomatic/improved). Performed with inverse-variance (IV) random effects meta-analysis using the Paule-Mandel between study heterogeneity estimator with modified Hartung-Knapp confidence intervals. 


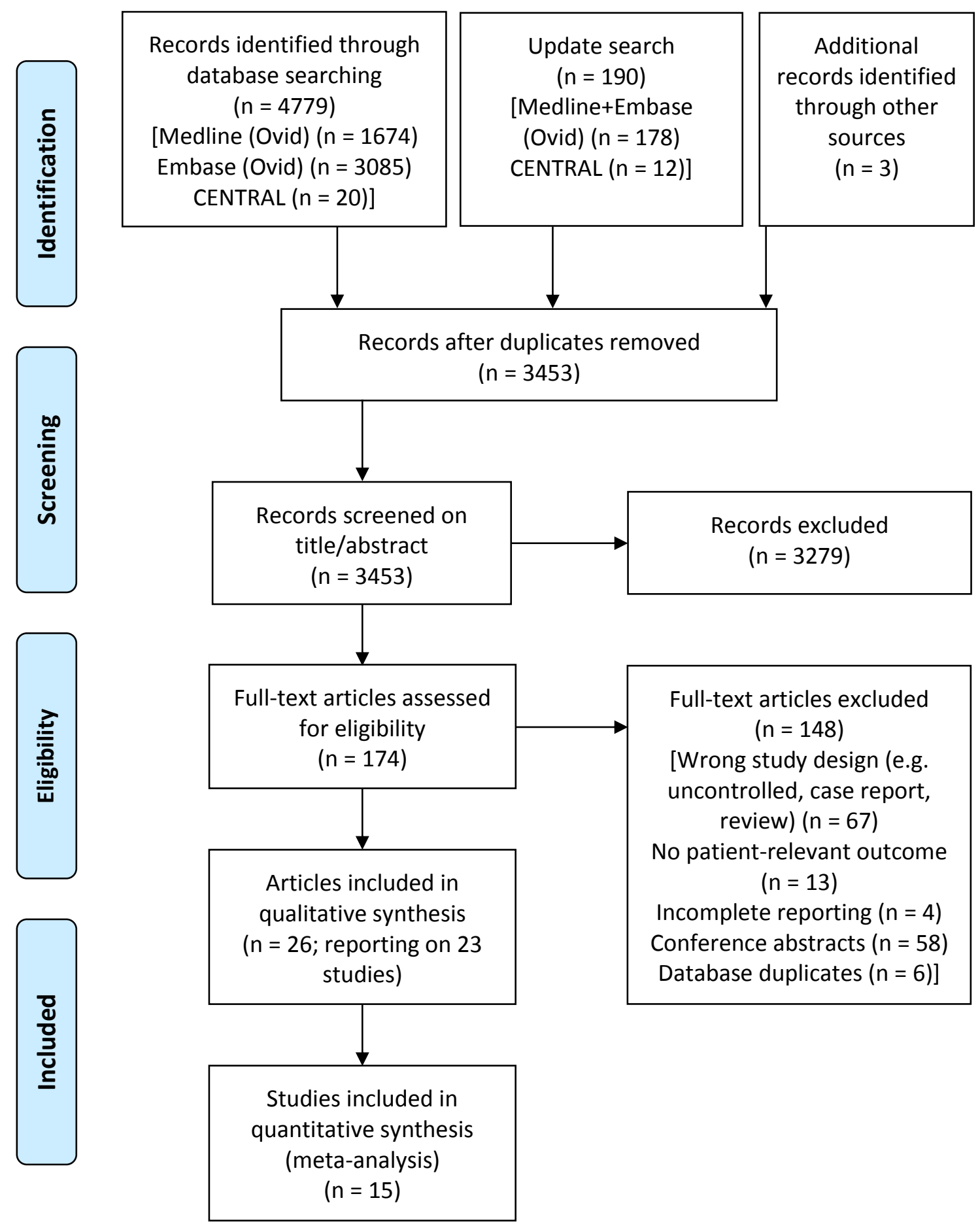




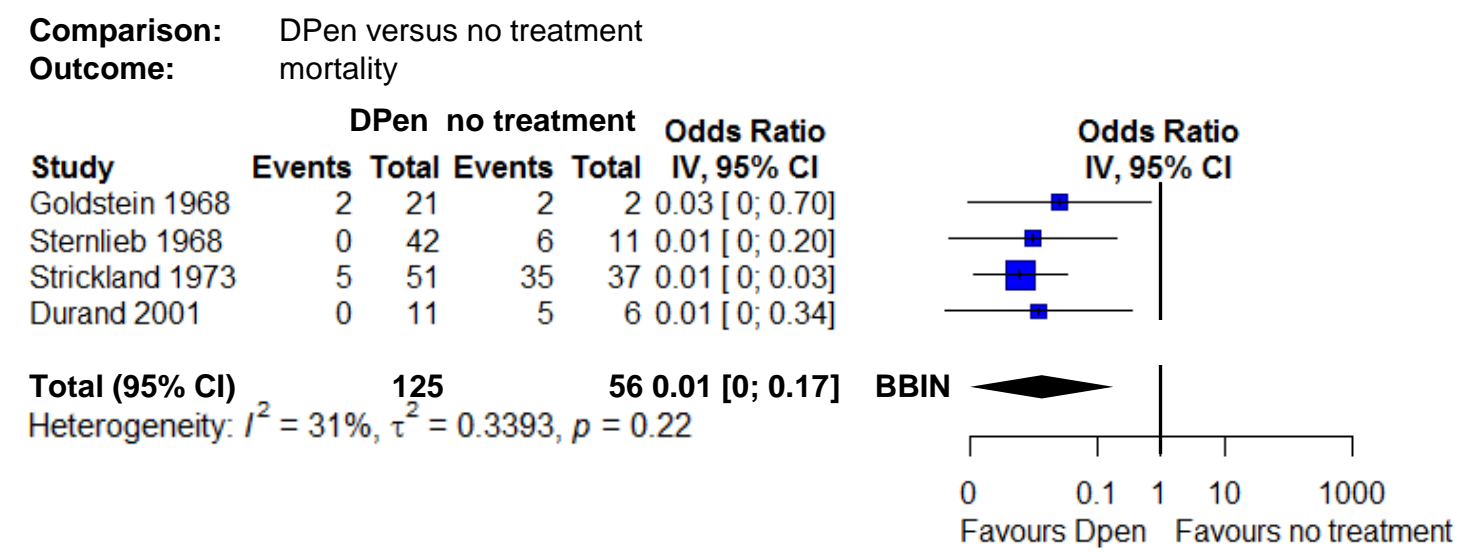



$\begin{array}{lll}\text { A Comparison: } & \text { DPen versus } \mathrm{Zn} \\ \text { Outcome: } & \text { mortality }\end{array}$

Study
Czlonkowska 1996
Czlonkowska 2005

DPen

Events Total

Zn Odds Ratio

Medici 2006

Weiss 2011

Ranucci 2014
Czlonkowska 2014

$\begin{array}{rr}3 & 34 \\ 10 & 79\end{array}$

$\begin{array}{rrrr} & \text { Total } & \text { IV, 95\% Cl } \\ 4 & 33 & 0.70[0.14 ; 3.41]\end{array}$

123

220

27

$811.32[0.49 ; 3.55]$

$1 \quad 230.10[0.01 ; 1.66]$

$\begin{array}{ll}1 & 23 \\ 0 & 15 \\ 1 & 72\end{array}$

Total $(95 \% \mathrm{Cl})$

454

724.24 [0.46; 38.90]

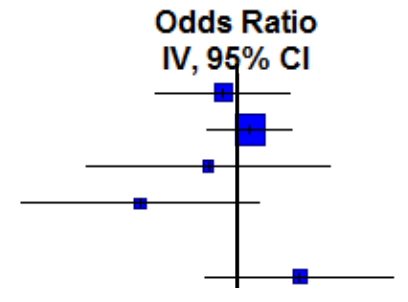

Heterogeneity: $I^{2}=37 \%, \tau^{2}=1.415, p=0.17$

$2360.74[0.16 ; 3.48]$
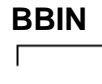

$\begin{array}{lllll}0.01 & 0.1 & 1 & 10 & 100\end{array}$

Favours DPen Favours Zn

B Comparison: DPen versus $\mathrm{Zn}$

Outcome: asymptomatic/improved

\begin{tabular}{lrrrrrc} 
& \multicolumn{2}{c}{$\begin{array}{c}\text { DPen } \\
\text { Study }\end{array}$} & $\begin{array}{c}\text { Zn } \\
\text { Events }\end{array}$ & Total Events & Total Weight & $\begin{array}{c}\text { Odds Ratio IV, } \\
\text { Random, 95\% Cl }\end{array}$ \\
Czlonkowska 1996 & 13 & 19 & 23 & 29 & $11.9 \%$ & $0.57[0.15 ; 2.12]$ \\
lorio 2004 & 58 & 87 & 11 & 22 & $23.2 \%$ & $2.00[0.78 ; 5.16]$ \\
Medici 2006 & 9 & 23 & 7 & 12 & $10.3 \%$ & $0.46[0.11 ; 1.90]$ \\
Weiss 2011 & 125 & 220 & 16 & 23 & $24.2 \%$ & $0.58[0.23 ; 1.46]$ \\
Bruha 2011 & 60 & 80 & 11 & 13 & $8.2 \%$ & $0.55[0.11 ; 2.67]$ \\
Rodriguez 2012 & 11 & 18 & 2 & 2 & $2.1 \%$ & $0.31[0.01 ; 7.32]$ \\
Czlonkowska 2014 & 63 & 71 & 63 & 72 & $20.2 \%$ & $1.12[0.41 ; 3.10]$ \\
& & & & & &
\end{tabular}

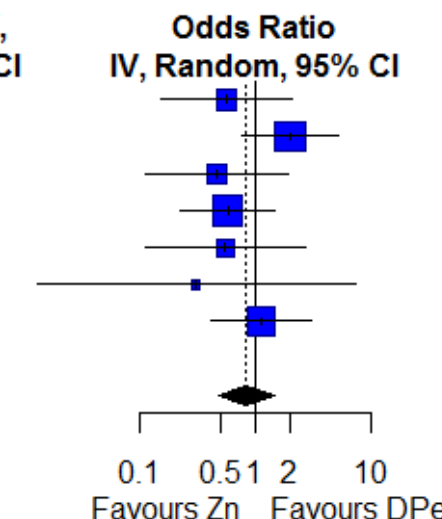

$\begin{array}{lcr}\text { Total }(\mathbf{9 5} \% \mathrm{Cl}) & \mathbf{5 1 8} & \mathbf{1 7 3} \\ \text { Heterogeneity: } \text { Tau }^{2}=0 ; \mathrm{Chi}^{2}=5.89, \mathrm{df}=6(\mathrm{P}=0.44) ; \mathrm{I}^{2}=0 \%\end{array}$

Favours Zn Favours DPen 


\section{Appendices}

\section{Appendix 1: Search strategies}

\section{MEDLINE (Ovid)}

November 30, 2017

1. (Wilson disease or wilsons disease or Wilson s disease or wilson syndrome or wilson degenerat* or morbus wilson or Kinnier-Wilson or Kinnier-Wilsons or Kinnier-Wilson $s$ or Pseudosclerosis or Westphal-Strumpell or Copper Storage Disease or Cerebral Pseudosclerosis or Cerebral Pseudoscleroses or hld or ((Hepatolenticular or Hepatocerebral or Neurohepatic or (Progressive and Lenticular)) and (Degenerat* or Syndrome))).ab,ti.

2. (3 mercaptovaline or 3,3 dimethylcysteine or adaleen or alpha amino beta methyl beta mercaptobutyric acid or alpha penicillamin or artamin or atamir or beta mercaptovaline or beta,beta dimethylcysteamine or beta, beta dimethylcysteine or byanodine or cuprenil or cuprim or cuprimin or cuprimine or cuprimune or cupripen or $d 3$ mercaptovaline or $d$ penicillamin or $d$ penicillamine or $d$ penicillamine hydrochloride or $\mathrm{d}$ penicillinamine hydrochloride or $\mathrm{d}$-penamine or $\mathrm{d}$-penil or delta penicillamine or depen or dextro penicillamine or dextropenicillamine or dimethyl cysteine or dimethylcysteine or distamine or dl penicillamine or gerodyl or kelatin or kelatine or I penicillamine or mercaptyl or metalcaptase or pemine or pendramine or penicilamina or penicillame or penicillamin or penicillamin $\mathrm{d}$ or penicillamine $\mathrm{d}$ or penicillamine hydrochloride or penicillinamine or racemic penicillamine or Penicillaminate or sufortanon or trolovol).ab,ti.

3. (1,8 diamino 3,6 diazaoctane or 3,6 diazaoctane 1,8 diamine or cuprid or laszarin or "mk 0681 " or mk 681 or mk0681 or mk681 or syprine or teta or trien or trientine dihydrochloride or trientine hydrochloride or trientine tetrahydrochloride or triethylene tetraamine or triethylene tetramide or triethylene tetramine or triethylenetetraamine or triethylenetetraamine dihydrochloride or triethylenetetramine or triethylenetetramine dihydrochloride).ab,ti.

4. (tetrathiomolybdate or TTM cpd or thiomolybdate or ATN-224 or WTX101).ab,ti.

5. (zinc or $64 Z n$ or zincum or $Z n$ or galzin or wilzin or zincasate or zinnax or op thal zin or solvazinc or solvezinc or verazinc or zincomed or zincteral).ab,ti.

6. exp Hepatolenticular Degeneration/

7. exp Penicillamine/

8. exp Trientine/

9. tetrathiomolybdate. $\mathrm{nm}$.

10. exp Zinc Acetate/ or exp Zinc/ or exp Zinc Sulfate/

11. 1 or 6

12. 2 or 7

13. 3 or 8

14. 4 or 9

15. 5 or 10

16. 12 or 13 or 14 or 15 


\section{11 and 16}

\section{Animals/}

19. Humans/

20. 17 not (18 not 19)

\section{Embase (Ovid)}

November 30, 2017

1. (Wilson disease or wilsons disease or Wilson s disease or wilson syndrome or wilson degenerat* or morbus wilson or Kinnier-Wilson or Kinnier-Wilsons or Kinnier-Wilson $s$ or Pseudosclerosis or Westphal-Strumpell or Copper Storage Disease or Cerebral Pseudosclerosis or Cerebral Pseudoscleroses or hld or ((Hepatolenticular or Hepatocerebral or Neurohepatic or (Progressive and Lenticular)) and (Degenerat* or Syndrome))).ab,ti.

2. (3 mercaptovaline or 3,3 dimethylcysteine or adaleen or alpha amino beta methyl beta mercaptobutyric acid or alpha penicillamin or artamin or atamir or beta mercaptovaline or beta,beta dimethylcysteamine or beta, beta dimethylcysteine or byanodine or cuprenil or cuprim or cuprimin or cuprimine or cuprimune or cupripen or $\mathrm{d} 3$ mercaptovaline or $\mathrm{d}$ penicillamin or d penicillamine or $\mathrm{d}$ penicillamine hydrochloride or $\mathrm{d}$ penicillinamine hydrochloride or $\mathrm{d}$-penamine or $\mathrm{d}$-penil or delta penicillamine or depen or dextro penicillamine or dextropenicillamine or dimethyl cysteine or dimethylcysteine or distamine or dl penicillamine or gerodyl or kelatin or kelatine or I penicillamine or mercaptyl or metalcaptase or pemine or pendramine or penicilamina or penicillame or penicillamin or penicillamin $\mathrm{d}$ or penicillamine $\mathrm{d}$ or penicillamine hydrochloride or penicillinamine or racemic penicillamine or Penicillaminate or sufortanon or trolovol).ab,ti.

3. (1,8 diamino 3,6 diazaoctane or 3,6 diazaoctane 1,8 diamine or cuprid or laszarin or "mk 0681 " or mk 681 or mk0681 or mk681 or syprine or teta or trien or trientine dihydrochloride or trientine hydrochloride or trientine tetrahydrochloride or triethylene tetraamine or triethylene tetramide or triethylene tetramine or triethylenetetraamine or triethylenetetraamine dihydrochloride or triethylenetetramine or triethylenetetramine dihydrochloride).ab,ti.

4. (tetrathiomolybdate or TTM cpd or thiomolybdate or ATN-224 or WTX101).ab,ti.

5. (zinc or 64Zn or zincum or Zn or galzin or wilzin or zincasate or zinnax or op thal zin or solvazinc or solvezinc or verazinc or zincomed or zincteral).ab,ti.

6. exp Wilson Disease/

7. exp Penicillamine/

8. exp Trientine/

9. exp Tetrathiomolybdic Acid/

10. exp Zinc Acetate/ or exp Zinc/ or exp Zinc Sulfate/

11. 1 or 6

12. 2 or 7

13. 3 or 8 
14. 4 or 9

15. 5 or 10

16. 12 or 13 or 14 or 15

17.11 and 16

18. Animal/

19. Human/

20. 17 not (18 not 19)

\section{CENTRAL}

November 30, 2017

Issue 10

\#1 Wilson disease or wilsons disease or Wilson s disease or wilson syndrome or wilson degenerat* or morbus wilson or Kinnier-Wilson or Kinnier-Wilsons or Kinnier-Wilson $\mathrm{s}$ or Pseudosclerosis or Westphal-Strumpell or Copper Storage Disease or Cerebral Pseudosclerosis or Cerebral Pseudoscleroses or hld or ((Hepatolenticular or Hepatocerebral or Neurohepatic or (Progressive and Lenticular)) and (Degenerat* or Syndrome)):ti,ab,kw

\#2 3 mercaptovaline or 3,3 dimethylcysteine or adaleen or alpha amino beta methyl beta mercaptobutyric acid or alpha penicillamin or artamin or atamir or beta mercaptovaline or beta,beta dimethylcysteamine or beta, beta dimethylcysteine or byanodine or cuprenil or cuprim or cuprimin or cuprimine or cuprimune or cupripen or $d 3$ mercaptovaline or d penicillamin or d penicillamine or $d$ penicillamine hydrochloride or d penicillinamine hydrochloride or $d$-penamine or d-penil or delta penicillamine or depen or dextro penicillamine or dextropenicillamine or dimethyl cysteine or dimethylcysteine or distamine or dl penicillamine or gerodyl or kelatin or kelatine or I penicillamine or mercaptyl or metalcaptase or pemine or pendramine or penicilamina or penicillame or penicillamin or penicillamin $d$ or penicillamine $d$ or penicillamine hydrochloride or penicillinamine or racemic penicillamine or Penicillaminate or sufortanon or trolovol:ti,ab,kw

\#31,8 diamino 3,6 diazaoctane or 3,6 diazaoctane 1,8 diamine or cuprid or laszarin or mk 0681 or mk 681 or mk0681 or mk681 or syprine or teta or trien or trientine dihydrochloride or trientine hydrochloride or trientine tetrahydrochloride or triethylene tetraamine or triethylene tetramide or triethylene tetramine or triethylenetetraamine or triethylenetetraamine dihydrochloride or triethylenetetramine or triethylenetetramine dihydrochloride:ti,ab,kw

\#4 tetrathiomolybdate or TTM cpd or thiomolybdate or ATN-224 or WTX101:ti,ab,kw

\#5 zinc or $64 \mathrm{Zn}$ or zincum or $\mathrm{Zn}$ or galzin or wilzin or zincasate or zinnax or op thal zin or solvazinc or solvezinc or verazinc or zincomed or zincteral:ti,ab,kw

\#6 MeSH descriptor: [Hepatolenticular Degeneration] explode all trees

\#7 MeSH descriptor: [Penicillamine] explode all trees

\#8 MeSH descriptor: [Trientine] explode all trees

\#9 MeSH descriptor: [Zinc] explode all trees 
\#10 MeSH descriptor: [Zinc Sulfate] explode all trees

\#11 MeSH descriptor: [Zinc Acetate] explode all trees

$\# 12$ (\#1 or \#6) and (\#2 or \#3 or \#4 or \#5 or \#7 or \#8 or \#9 or \#10 or \#11)

\#13 MeSH descriptor: [Animals] explode all trees

\#14 MeSH descriptor: [Humans] explode all trees

\#15 \#12 not (\#13 not \#14)

\section{Update search}

January 31, 2019

The above Ovid search strategies were combined (with MeSH and Emtree terms combined with OR), and search results from Medline and Embase directly deduplicated in Ovid. This search was limited to 01 January 2017 to 31 January 2019.

The search strategy for CENTRAL was rerun in the Cochrane library. The search time range was not limited. 
Table S1: Characteristics of 144 excluded studies [ordered by first-author

names]

Note that de Bem 2011, Fadda 2012, Leiros Da Costa 2009, and Silva 1996 are database duplicates, explaining the difference between 144 versus 148 excluded studies (compare to Figure 1).

\begin{tabular}{|c|c|}
\hline Study & Reason for exclusion \\
\hline Abdel Ghaffar $2011^{1}$ & Wrong study design (analysis of outcome not linked to treatment) \\
\hline Aggarwal 2014² & Conference abstract \\
\hline Aggarwal $2017^{3}$ & Conference abstract \\
\hline Al Fadda $2012^{4}$ & Wrong study design (uncontrolled) \\
\hline Alam 2013 & Conference abstract \\
\hline Aposhian $1971^{6}$ & Wrong study design (review) \\
\hline Arnon $2007^{7}$ & Wrong study design (uncontrolled) \\
\hline Askari $2003^{8}$ & Wrong study design (uncontrolled) \\
\hline Avan $2013^{9}$ & Conference abstract \\
\hline Avan $2015^{10}$ & Conference abstract \\
\hline Avinashi $2009^{11}$ & Conference abstract \\
\hline Bachmann $1989^{12}$ & Wrong study design (uncontrolled) \\
\hline Baeg 2015 & Conference abstract \\
\hline Bagchi $2012^{14}$ & Conference abstract \\
\hline Barbosa $1991^{15}$ & Wrong study design (uncontrolled) \\
\hline Beinhardt 2012 ${ }^{16}$ & Conference abstract \\
\hline Bem 2011 & Wrong study design (analysis of outcome not linked to treatment) \\
\hline Berenguer $2017^{18}$ & Conference abstract \\
\hline Bono $2002^{19}$ & Wrong study design (analysis of outcome not linked to treatment) \\
\hline Brewer $1995^{20}$ & Wrong study design (review) \\
\hline Brewer 199621 & Wrong study design (uncontrolled) \\
\hline Brewer $1997^{22}$ & Wrong study design (uncontrolled) \\
\hline Brewer $2003^{23}$ & Wrong study design (uncontrolled) \\
\hline Brewer 2006 24 & Database duplicate (included article) \\
\hline Brewer $2008^{25}$ & Database duplicate (included article) \\
\hline Burke 201126 & Wrong study design (analysis of outcome not linked to treatment) \\
\hline Chu $1993^{27}$ & Wrong study design (review) \\
\hline Cossack $1986^{28}$ & No patient-relevant outcome (copper balance) \\
\hline Czlonkowska $2010^{29}$ & Conference abstract \\
\hline Czlonkowska $2013^{30}$ & Conference abstract \\
\hline
\end{tabular}




\begin{tabular}{|c|c|}
\hline Czlonkowska $2015^{31}$ & Conference abstract \\
\hline da Costa Mdo $2009^{32}$ & Incomplete reporting of treatment regimen \\
\hline Dastych $2010^{33}$ & No patient-relevant outcome (Elements in serum, urine, and hair) \\
\hline de Bem 2011 & Database duplicate (see Ref. 17) \\
\hline De Sousa $2017^{34}$ & Conference abstract \\
\hline Deiss $1^{1971}$ & Wrong study design (uncontrolled) \\
\hline Demir 2014 & Conference abstract \\
\hline Denny-Brown $1964^{37}$ & Wrong study design (case series) \\
\hline Dubbioso $2016^{38}$ & Wrong study design (neurological vs. non-neurological) \\
\hline Dziezyc $2014^{39}$ & No patient-relevant outcome (compliance) \\
\hline El Machkour $2011^{40}$ & Wrong study design (case series) \\
\hline El-Karaksy $2011^{41}$ & Wrong study design (analysis of outcome not linked to treatment) \\
\hline Engelbrecht $1995^{42}$ & Wrong study design (case report) \\
\hline Esposito $2013^{43}$ & Conference abstract \\
\hline Estevo $2012^{44}$ & Conference abstract \\
\hline Fadda $2009^{45}$ & Conference abstract \\
\hline Fadda 2012 & Database duplicate (see Ref. 4) \\
\hline Gill $1994^{46}$ & Wrong study design (case series) \\
\hline Girardot-Tinant $2012^{47}$ & Conference abstract \\
\hline Goldstein $1963^{48}$ & No patient-relevant outcome (copper balance) \\
\hline Goldstein $1965^{49}$ & No patient-relevant outcome (copper balance) \\
\hline Gromadzka $2014^{50}$ & No patient-relevant outcome (antioxidant capacity) \\
\hline Gupta $2017^{51}$ & Conference abstract \\
\hline Gupta $2018^{52}$ & Wrong study design (uncontrolled) \\
\hline Harders $1977^{53}$ & Wrong study design (case report) \\
\hline Hefter $2018^{54}$ & Incomplete reporting of treatment regimen \\
\hline Hill $1986^{55}$ & Wrong study design (mechanistic) \\
\hline Hoogenraad $1987^{56}$ & Wrong study design (uncontrolled) \\
\hline Hsia $1966^{57}$ & No patient-relevant outcome (copper balance) \\
\hline Hui $2011^{58}$ & Conference abstract \\
\hline Idrissi $2013^{59}$ & Wrong study design (analysis of outcome not linked to treatment) \\
\hline Jablonska $2003^{60}$ & Wrong study design (uncontrolled) \\
\hline Janczyk 200961 & Conference abstract \\
\hline Janczyk 2016 22 & Conference abstract \\
\hline Janczyk 2017 & Conference abstract \\
\hline Kalita $2014^{64}$ & Wrong study design (analysis of outcome not linked to treatment) \\
\hline Kalita $2015^{65}$ & Wrong study design (analysis of outcome not linked to treatment) \\
\hline Kalra $2000^{66}$ & Wrong study design (uncontrolled) \\
\hline Kazemi $2008^{67}$ & Wrong study design (cross-sectional) \\
\hline Kleine $2012^{68}$ & Wrong study design (uncontrolled) \\
\hline Kondou $2013^{69}$ & Conference abstract \\
\hline Kucinskas 2008 ${ }^{70}$ & Wrong study design (genetic study) \\
\hline Kumar 2010 & Conference abstract \\
\hline Kumar 2012a $a^{72}$ & Conference abstract \\
\hline Kumar $2012 b^{73}$ & Conference abstract \\
\hline
\end{tabular}




\begin{tabular}{|c|c|}
\hline Kunath $2003^{74}$ & Wrong study design (analysis of outcome not linked to treatment) \\
\hline Lapeyre $2010^{75}$ & Conference abstract \\
\hline Leiros Da Costa 2009 & Database duplicate (see Ref. 32) \\
\hline Lingam $1987^{76}$ & Wrong study design (case series) \\
\hline Lossner $1980^{77}$ & Wrong study design (uncontrolled) \\
\hline Manolaki $2009^{78}$ & Wrong study design (analysis of outcome not linked to treatment) \\
\hline Medici $2007^{79}$ & No patient-relevant outcome (hepatic iron concentration) \\
\hline Mercier-Jacquier $2011^{80}$ & Wrong study design (uncontrolled) \\
\hline Moores $2010^{81}$ & Conference abstract \\
\hline Moores $2011^{82}$ & Conference abstract \\
\hline Moores $2012^{83}$ & Incomplete reporting \\
\hline Ogihara $1995^{84}$ & No patient-relevant outcome (antioxidant capacity) \\
\hline Osborn $1958^{85}$ & No patient-relevant outcome (copper excretion) \\
\hline Park $1991^{86}$ & Wrong study design (analysis of outcome not linked to treatment) \\
\hline Parkash 2012a ${ }^{87}$ & Conference abstract \\
\hline Parkash 2012b ${ }^{88}$ & Conference abstract \\
\hline Pellecchia $2003^{89}$ & Wrong study design (analysis of outcome not linked to treatment) \\
\hline Pfeiffenberger ${ }^{90}$ & No patient-relevant outcome (urinary and serum copper levels) \\
\hline Pietrobattista $2010^{91}$ & Conference abstract \\
\hline Poujois 2016 & Conference abstract \\
\hline Poujois 2018 & Wrong study design (cross-sectional) \\
\hline Ramachandiran $2012^{94}$ & Conference abstract \\
\hline Ranucci $2011^{95}$ & Conference abstract \\
\hline Ranucci $2012^{96}$ & Conference abstract \\
\hline Ranucci $2013^{97}$ & Conference abstract \\
\hline Ranucci $2016^{98}$ & Conference abstract \\
\hline Ras $2010^{99}$ & Conference abstract \\
\hline Richmond $1964^{100}$ & Wrong study design (case series) \\
\hline Rodrigo Agudo $2008^{101}$ & Wrong study design (analysis of outcome not linked to treatment) \\
\hline Saito $1991^{102}$ & $\begin{array}{l}\text { Wrong study design (uncontrolled) } \\
\text { For the controlled part: No patient-relevant outcome (urinary copper } \\
\text { excretion) }\end{array}$ \\
\hline Sanchez $1997^{103}$ & Wrong study design (uncontrolled) \\
\hline Santiago $2015^{104}$ & Wrong study design (uncontrolled) \\
\hline Santos Silva $1996^{105}$ & Wrong study design (analysis of outcome not linked to treatment) \\
\hline Sarapura $2017^{106}$ & Conference abstract \\
\hline Scheinberg $1987^{107}$ & Wrong study design (drug continuation vs discontinuation) \\
\hline Schilsky $1991^{108}$ & Wrong study design (uncontrolled) \\
\hline Schlaug $1996^{109}$ & Wrong study design (analysis of outcome not linked to treatment) \\
\hline Seesle $2012^{110}$ & Conference abstract \\
\hline Seignette $1959^{111}$ & Wrong study design (case series) \\
\hline Shahar $2013^{112}$ & Conference abstract \\
\hline Silva 1996 & Database duplicate (see Ref. 99) \\
\hline Sinha $2006^{113}$ & Incomplete reporting of treatment regimen \\
\hline Sinha $2008^{114}$ & Wrong study design (uncontrolled) \\
\hline Sintusek 2016 & Wrong study design (uncontrolled) \\
\hline
\end{tabular}




\begin{tabular}{|c|c|}
\hline Sobesky $2016^{116}$ & Conference abstract \\
\hline Sobesky $2017^{117}$ & Conference abstract \\
\hline Soyer $2014^{118}$ & Conference abstract \\
\hline Starosta-Rubinstein $1987^{119}$ & Wrong study design (uncontrolled) \\
\hline Strickland $1971^{120}$ & No patient-relevant outcome (copper balance) \\
\hline Tai $2016^{121}$ & Conference abstract \\
\hline Taly $2007^{122}$ & Wrong study design (analysis of outcome not linked to treatment) \\
\hline Taylor $2009^{123}$ & Wrong study design (uncontrolled) \\
\hline Teive $2012^{124}$ & Conference abstract \\
\hline Trocello $2010^{125}$ & Conference abstract \\
\hline Valmary $1992^{126}$ & Conference abstract \\
\hline Van Caillie-Bertrand $1985^{127}$ & Wrong study design (uncontrolled) \\
\hline Vandriel $2017^{128}$ & Conference abstract \\
\hline Viswanathan $2009^{129}$ & Conference abstract \\
\hline Walshe $1973^{130}$ & No patient-relevant outcome (serum and urinary copper) \\
\hline Walshe $1982^{131}$ & Wrong study design (uncontrolled) \\
\hline Walshe $1993^{132}$ & Wrong study design (analysis of outcome not linked to treatment) \\
\hline Walshe $2007^{133}$ & Wrong study design (analysis of outcome not linked to treatment) \\
\hline Wang $2010^{134}$ & Wrong study design (analysis of outcome not linked to treatment) \\
\hline Wang $2016^{135}$ & Conference abstract \\
\hline Weiss 2011a ${ }^{136}$ & Conference abstract \\
\hline Weiss 2011b ${ }^{137}$ & Conference abstract \\
\hline Wiernicka $2013^{138}$ & Wrong study design (uncontrolled) \\
\hline Wiernicka $2017^{139}$ & Wrong study design (analysis of outcome not linked to treatment) \\
\hline Wu 2014 & Conference abstract \\
\hline Xu $2013^{141}$ & Wrong study design (alternating regimen) \\
\hline Yuce $2000^{142}$ & Wrong study design (uncontrolled) \\
\hline Yuce $2010^{143}$ & Conference abstract \\
\hline Zhang $2018^{144}$ & Wrong study design (wrong comparator) \\
\hline
\end{tabular}


Table S2: Results of quality assessment using the Newcastle-Ottawa Scale for cohort studies and the RoB 2.0 tool for randomized controlled trials

Newcastle-Ottawa Scale

\begin{tabular}{|c|c|c|c|c|c|c|c|c|c|}
\hline $\begin{array}{l}\text { FIRST } \\
\text { AUTHOR, } \\
\text { YEAR }\end{array}$ & $\begin{array}{l}\text { REPRESENTATIVE- } \\
\text { NESS OF THE } \\
\text { EXPOSED COHORT }\end{array}$ & $\begin{array}{l}\text { SELECTION } \\
\text { OF THE } \\
\text { NON- } \\
\text { EXPOSED } \\
\text { COHORT }\end{array}$ & $\begin{array}{l}\text { ASCERTAINMENT } \\
\text { OF EXPOSURE }\end{array}$ & $\begin{array}{l}\text { DEMONSTRATION } \\
\text { THAT OUTCOME } \\
\text { OF INTEREST WAS } \\
\text { NOT PRESENT AT } \\
\text { START OF STUDY }\end{array}$ & $\begin{array}{l}\text { COMPARABILITY } \\
\text { OF COHORTS } \\
\text { ON THE BASIS } \\
\text { OF THE DESIGN } \\
\text { OR ANALYSIS }\end{array}$ & $\begin{array}{l}\text { ASSESSMENT } \\
\text { OF } \\
\text { OUTCOME }\end{array}$ & $\begin{array}{l}\text { FOLLOW- } \\
\text { UP LENGTH } \\
\text { IN } \\
\text { RELATION } \\
\text { TO } \\
\text { OUTCOME } \\
\text { INCIDENCE }\end{array}$ & $\begin{array}{l}\text { ADEQUACY } \\
\text { OF } \\
\text { FOLLOW- } \\
\text { UP OF } \\
\text { COHORTS }\end{array}$ & $\begin{array}{l}\text { TOTAL } \\
\text { SCORE }\end{array}$ \\
\hline $\begin{array}{l}\text { Goldstein, } \\
1968\end{array}$ & $\star$ & $\star$ & $\star$ & $\star$ & 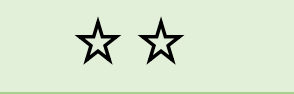 & $\star$ & $\star$ & $\star$ & 7 \\
\hline $\begin{array}{l}\text { Sternlieb, } \\
1968\end{array}$ & $\star$ & $\star$ & $\star$ & $\star$ & $\lambda^{2}$ & $\star$ & 光 & 功 & 5 \\
\hline $\begin{array}{l}\text { Strickland, } \\
1973\end{array}$ & $\star$ & 象 & $\star$ & $\star$ & 蛋 & $\star$ & 象 & 氙 & 4 \\
\hline $\begin{array}{l}\text { Durand, } \\
2001\end{array}$ & $\star$ & 功 & $\star$ & $\star$ & 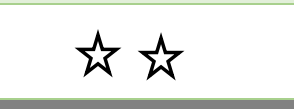 & $\star$ & $\star$ & 象 & 5 \\
\hline Weiss, 2011 & $\star$ & $\vec{x}$ & $\star$ & $\star$ & 蛋 & $\star$ & $\star$ & 幽 & 5 \\
\hline Sini, 2013 & $\star$ & $\star$ & $\star$ & $\star$ & 必支 & $\star$ & $\star$ & $\star$ & 7 \\
\hline $\begin{array}{l}\text { Seessle, } \\
2016\end{array}$ & $\star$ & $\star$ & $\star$ & $\star$ & 赴去 & $\star$ & 象 & 氙 & 5 \\
\hline Tai, 2018 & $\star$ & $\star$ & $\star$ & $\star$ & $\dot{\lambda}$ & $\star$ & $\star$ & 功 & 6 \\
\hline $\begin{array}{l}\text { Czlonkowska } \\
1996\end{array}$ & $\star$ & $\star$ & $\star$ & $\star$ & 农卖 & $\star$ & $\star$ & $\star$ & 7 \\
\hline
\end{tabular}




\begin{tabular}{|c|c|c|c|c|c|c|c|c|c|}
\hline Iorio, 2004 & $\star$ & $\star$ & $\star$ & $\star$ & 头农 & $\star$ & $\star$ & $\dot{x}$ & 6 \\
\hline $\begin{array}{l}\text { Czlonkowska } \\
\text {, } 2005\end{array}$ & $\star$ & $\star$ & $\star$ & $\star$ & 我交 & $\star$ & 功 & 光 & 5 \\
\hline Medici, 2006 & $\star$ & $\star$ & $\star$ & $\star$ & 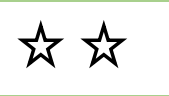 & $\star$ & $\star$ & 头 & 6 \\
\hline Svetel, 2009 & 次 & 功 & $\star$ & $\star$ & 光 & $\star$ & $\star$ & 弐 & 4 \\
\hline $\begin{array}{l}\text { Cope- } \\
\text { Yokoyama, } \\
2010\end{array}$ & 起 & $\star$ & $\star$ & $\star$ & 我交 & $\star$ & $\star$ & $\star$ & 6 \\
\hline Bruha, 2011 & $\star$ & $\star$ & $\star$ & $\star$ & 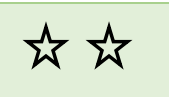 & $\star$ & $\star$ & 幽 & 6 \\
\hline $\begin{array}{l}\text { Rodriguez, } \\
2012\end{array}$ & 象 & 氛 & $\star$ & $\star$ & 卖产 & $\star$ & $\star$ & 光 & 4 \\
\hline $\begin{array}{l}\text { Ranucci, } \\
2014\end{array}$ & 光 & 光 & $\star$ & $\star$ & 光 & $\star$ & $\star$ & 龶 & 4 \\
\hline $\begin{array}{l}\text { Czlonkowska } \\
\text {, } 2014\end{array}$ & $\star$ & $\star$ & $\star$ & $\star$ & $\star \star \star$ & $\star$ & $\star$ & 功 & 8 \\
\hline $\begin{array}{l}\text { Vieira } \\
\text { Barbosa, } \\
2018\end{array}$ & $\star$ & 弐 & $\star$ & $\star$ & 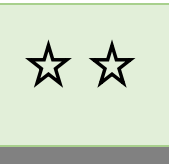 & $\star$ & 弐 & 弐 & 4 \\
\hline $\begin{array}{l}\text { Kumagi, } \\
2004\end{array}$ & $\star$ & 功 & $\star$ & 幽 & 头讼 & 光 & 头 & 功 & 2 \\
\hline Weiss, 2013 & $\star$ & $\star$ & $\star$ & $\star$ & 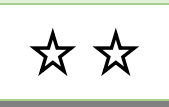 & $\star$ & $\star$ & 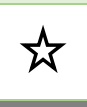 & 6 \\
\hline Ren, 1998 & $\star$ & $\star$ & $\star$ & $\star$ & 丞交 & $\star$ & 功 & $\star$ & 6 \\
\hline
\end{tabular}

$\star$ Score 1 point, $\quad$ th Score 0 point. 
RoB 2.0 tool for randomized controlled trials

\begin{tabular}{|c|c|c|c|c|c|c|}
\hline $\begin{array}{l}\text { FIRST } \\
\text { AUTHOR, } \\
\text { YEAR }\end{array}$ & $\begin{array}{l}\text { BIAS ARISING FROM } \\
\text { THE RANDOMIZATION } \\
\text { PROCESS }\end{array}$ & $\begin{array}{l}\text { BIAS DUE TO DEVIATIONS } \\
\text { FROM INTENDED } \\
\text { INTERVENTIONS }\end{array}$ & $\begin{array}{l}\text { BIAS DUE TO } \\
\text { MISSING } \\
\text { OUTCOME DATA }\end{array}$ & $\begin{array}{l}\text { BIAS IN MEASUREMENT } \\
\text { OF THE OUTCOME }\end{array}$ & $\begin{array}{l}\text { BIAS IN SELECTION OF } \\
\text { THE REPORTED } \\
\text { RESULT }\end{array}$ & OVERALL BIAS \\
\hline Brewer, 2006 & th & $\star$ & th & $\star$ & th & t \\
\hline
\end{tabular}




\section{Table S3: Overview of outcome events per included study}

Overview for mortality, asymptomatic, asymptomatic/improved, OLT, side effects, (irreversible) neurologic deterioration, and treatment discontinuation

\begin{tabular}{|c|c|c|c|c|c|c|c|c|}
\hline & $\begin{array}{l}\text { Clinical } \\
\text { presentation: }\end{array}$ & Mortality & Asymptomatic & $\begin{array}{l}\text { Asymptomatic/ } \\
\text { improved }\end{array}$ & OLT & Side effects & $\begin{array}{l}\text { Neurologic } \\
\text { deterioration } \\
\text { [irreversible] }\end{array}$ & $\begin{array}{l}\text { Treatment discontinuation } \\
\text { [reasons] }\end{array}$ \\
\hline \multicolumn{9}{|c|}{ D-Penicillamine versus no treatment: Number of patients with event / Total number of patients (\%) } \\
\hline $\begin{array}{l}\text { Goldstein, } \\
1968\end{array}$ & $\begin{array}{r}\text { presymptomatic } \\
\text { hepatic } \\
\text { hepato-neurologic } \\
\text { neurologic }\end{array}$ & $\begin{array}{l}0 / 2 \text { (0) vs. } 0 / 0(0) \\
0 / 1(0) \text { vs. } 1 / 1(100) \\
1 / 4(25) \text { vs. } 1 / 1(100) \\
1 / 14 \text { (7) vs. } 0 / 0(0)\end{array}$ & $\begin{array}{l}2 / 2(100) \text { vs. } 0 / 0(0) \\
0 / 1(0) \text { vs. } 0 / 1(0) \\
0 / 4(0) \text { vs. } 0 / 1(0) \\
2 / 14(100) \text { vs. } 0 / 0(0)\end{array}$ & $\begin{array}{l}2 / 2(100) \text { vs. } 0 / 0(0) \\
1 / 1(100) \text { vs. } 0 / 1(0) \\
3 / 4(75) \text { vs. } 0 / 1(0) \\
14 / 14(100) \text { vs. } 0 / 0(0) \\
\end{array}$ & & & & \\
\hline $\begin{array}{l}\text { Sternlieb, } \\
1968\end{array}$ & presymptomatic & $0 / 42(0)$ vs. $6 / 11(55)$ & $42 / 42(100)$ vs. 0/11 (0) & & & & & \\
\hline $\begin{array}{l}\text { Strickland, } \\
1973\end{array}$ & $\begin{array}{r}\text { presymptomatic } \\
\text { symptomatic }\end{array}$ & $\begin{array}{l}1 / 16(6) \text { vs. } 0 / 1(0) \\
4 / 35(11) \text { vs. } 35 / 36(100)\end{array}$ & $\begin{array}{l}15 / 16(94) \text { vs. } 1 / 1(100) \\
18 / 35(51) \text { vs. } 0 / 36(0)\end{array}$ & & & & & \\
\hline Durand, 2001 & hepatic & 0/11 (0) vs. 5/6 (83) & & & $1 / 11$ (9) vs. $2 / 6$ (33) & & & \\
\hline \multicolumn{9}{|c|}{ D-Penicillamine versus trientine versus zinc salts: Number of patients with event / Total number of patients (\%) } \\
\hline $\begin{array}{l}\text { Weiss, 2011† } \\
\text { (Merle, 2007) }\end{array}$ & $\begin{array}{r}\text { presymptomatic } \\
\text { hepatic } \\
\text { hepato-neurologic } \\
\text { neurologic }\end{array}$ & $\begin{array}{l}\text { all presentations: } \\
1 / 220(0) \text { vs. } 0 / 24 \text { (0) vs. } \\
1 / 23(4 \%)\end{array}$ & & $\begin{array}{l}16 / 29(55) \text { vs. } 1 / 1(100) \text { vs. } 0 / 0(0) \\
85 / 131(65) \text { vs. } 8 / 13(62) \text { vs. } 13 / 18 \\
(72) \\
8 / 19(42) \text { vs. } 2 / 5(40) \text { vs. } 0 / 0(0) \\
16 / 41(39) \text { vs. } 4 / 5(80) \text { vs. } 3 / 5(60)\end{array}$ & & $\begin{array}{l}\text { all presentations: } \\
147 / 220(67) \text { vs. } 8 / 24 \text { (33) } \\
\text { vs. } 7 / 23(30)\end{array}$ & $\begin{array}{l}\text { NA } \\
\text { NA } \\
13 / 60(22) \text { vs. } 1 / 10(10) \text { vs. } \\
1 / 5(20)\end{array}$ & 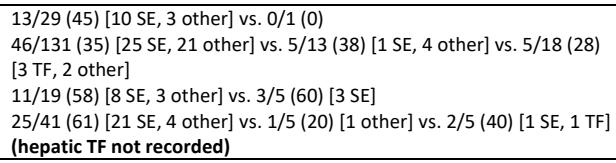 \\
\hline Tai, 2018 & any & & & & & & & $29 / 54(54)$ vs. $0 / 4$ (0) vs. $0 / 8(0)$ \\
\hline \multicolumn{9}{|c|}{ D-Penicillamine versus zinc salts: Number of patients with event / Total number of patients (\%) } \\
\hline $\begin{array}{l}\text { Czlonkowska, } \\
1996\end{array}$ & $\begin{array}{r}\text { presymptomatic } \\
\text { hepatic } \\
\text { neurologic }\end{array}$ & $\begin{array}{l}0 / 3(0) \text { vs. } 0 / 8(0 \%) \\
3 / 31(10) \text { vs } 4 / 25(16) \\
\text { (hepatic or neurologic } \\
\text { presentation) }\end{array}$ & & $\begin{array}{l}2 / 2(100) \text { vs. } 8 / 8(100) \\
11 / 17(65) \text { vs. } 15 / 21 \text { (71) (hepatic or } \\
\text { neurologic patients) }\end{array}$ & & $\begin{array}{l}\text { all presentations: } \\
10 / 34(29) \text { vs. } 2 / 33(6)\end{array}$ & & $\begin{array}{l}\text { all presentations: } \\
15 / 34(44) \text { [10 SE, } 5 \text { TF] vs. 4/33 (12) [2 SE, } 2 \text { TF] }\end{array}$ \\
\hline lorio, 2004 & $\begin{array}{r}\text { presymptomatic } \\
\text { hepatic } \\
\text { neurologic } \\
\end{array}$ & & & $\begin{array}{l}\frac{\text { all presentations: }}{58 / 87(67) \text { vs. 11/22 (50) }} \\
\end{array}$ & $\begin{array}{l}\text { all presentations: } \\
1 / 87 \text { (1) vs. } 0 / 22 \text { (0) }\end{array}$ & $\begin{array}{l}\text { all presentations: } \\
5 / 87(6) \text { vs. } 0 / 22(0)\end{array}$ & & $\begin{array}{l}\text { all presentations: } \\
17 / 87(20)[5 \mathrm{SE}, 12 \mathrm{TF}] \text { vs. } 5 / 22(23)[5 \mathrm{TF}]\end{array}$ \\
\hline $\begin{array}{l}\text { Czlonkowska, } \\
2005\end{array}$ & any & $10 / 79(13)$ vs. $8 / 81(10)$ & & & & & & \\
\hline Medici, 2006 & $\begin{array}{r}\text { hepatic } \\
\text { hepato-neurologic }\end{array}$ & $\begin{array}{l}0 / 15 \text { (0) vs. } 0 / 8(0) \\
1 / 8(13) \text { vs. } 1 / 4(25)\end{array}$ & & $\begin{array}{l}7 / 15(47) \text { vs. } 5 / 8(63) \\
2 / 8(25) \text { vs. } 2 / 4(75)\end{array}$ & $\begin{array}{l}1 / 15(7) \text { vs. } 1 / 8(0) \\
0 / 8(0) \text { vs. } 2 / 4(50)\end{array}$ & $\frac{\text { all presentations: }}{6 / 23(26) \text { vs. } 4 / 12(33)}$ & $\begin{array}{l}\text { NA } \\
6 / 8(75) \text { vs. } 0 / 4(0)\end{array}$ & $\begin{array}{l}8 / 15(53)[4 \mathrm{SE}, 4 \mathrm{TF}] \text { vs. } 2 / 8(25)[2 \mathrm{TF}] \\
8 / 8(100)[2 \mathrm{SE}, 6 \mathrm{END}] \text { vs. 0/4 (0\%) }\end{array}$ \\
\hline Bruha, 2011 & $\begin{array}{r}\text { presymptomatic } \\
\text { hepatic } \\
\text { neurologic }\end{array}$ & & & $\begin{array}{l}8 / 8(100) \text { vs. } 2 / 2(100) \\
26 / 34(76) \text { vs. } 7 / 8(88) \\
26 / 38(68) \text { vs. } 2 / 3(67)\end{array}$ & & $\begin{array}{l}\text { all presentations: } \\
35 / 99(35) \text { vs. } 0 / 13(0)\end{array}$ & & $\begin{array}{l}\frac{\text { treatment discontinuation }}{1 / 9(11)[1 \mathrm{SE}] \mathrm{vs} .0 / 2(0)} \\
6 / 40(15)[3 \mathrm{SE}, 3 \text { other] vs. } 0 / 8(0) \\
21 / 50(42)[8 \mathrm{SE}, 10 \mathrm{TF}, 3 \text { other] vs. } 0 / 3(0)\end{array}$ \\
\hline
\end{tabular}




\begin{tabular}{|c|c|c|c|c|c|c|c|}
\hline $\begin{array}{l}\text { Rodriguez, } \\
2012\end{array}$ & $\begin{array}{r}\text { presymptomatic } \\
\text { hepatic } \\
\text { hepato-neurologic } \\
\text { neurologic }\end{array}$ & & $\begin{array}{l}\text { all presentations: } \\
11 / 18(61) \text { vs. } 2 / 2(100)\end{array}$ & $\begin{array}{l}0 / 0(0) \text { vs. } 0 / 2(0) \\
1 / 10(10) \text { vs. } 0 / 0(0) \\
0 / 3(0) \text { vs. } 0 / 0(0) \\
0 / 5(0) \text { vs. } 0 / 0(0)\end{array}$ & $\begin{array}{l}\text { all presentations: } \\
\text { 4/18 (22) vs. NR }\end{array}$ & & $\begin{array}{l}\text { all presentations: } \\
13 / 18(72)[4 \mathrm{SE}, 3 \mathrm{TF}, 6 \text { other] vs. } 0 / 2(0)\end{array}$ \\
\hline Ranucci, 2014 & hepatic & $0 / 27$ (0) vs. $0 / 15(0)$ & $20 / 27$ (74) vs. $13 / 15$ (87) & $0 / 27$ (0) vs. $0 / 15$ (0) & $10 / 27$ (37) vs. $13 / 15$ (87) & $3 / 27$ (11) vs. 0/15 (0) & $19 / 27(70)$ vs. $2 / 15(13)$ \\
\hline $\begin{array}{l}\text { Czlonkowska, } \\
2014 \\
\text { (Litwin, 2015) }\end{array}$ & $\begin{array}{r}\text { hepatic } \\
\text { neurologic }\end{array}$ & $\begin{array}{l}0 / 36(0) \text { vs. } 0 / 51(0) \\
4 / 35(11) \text { vs. } 1 / 21(5)\end{array}$ & $\begin{array}{l}34 / 36(94) \text { vs. } 48 / 51(94) \\
29 / 35(83) \text { vs. } 15 / 21(71)\end{array}$ & & & $\begin{array}{l}\text { NA } \\
12 / 35(34)[4(12)] \text { vs. } 4 / 21 \\
(19)[1(5)]\end{array}$ & $\begin{array}{l}11 / 36 \text { (31) vs. 6/51 (12) } \\
7 / 35 \text { (20) [11 SE, } 2 \text { TF, } 3 \text { END, } 2 \text { other] vs. } 5 / 21 \text { (24) [2 SE, } 6 \text { TF, } 3 \text { END] }\end{array}$ \\
\hline $\begin{array}{l}\text { Vieira } \\
\text { Barbosa, } \\
2018\end{array}$ & hepatic & $0 / 6$ (0) vs. $0 / 2(0)$ & & $3 / 6(50)$ vs. $0 / 2(0)$ & & & $3 / 6$ (50) [3 SE] vs. $2 / 2$ (100) [2 other] \\
\hline \multicolumn{8}{|c|}{ D-Penicillamine versus trientine: Number of patients with event / Total number of patients (\%) } \\
\hline Kumagi, 2004 & $\begin{array}{r}\begin{array}{r}\text { presymptomatic } \\
\text { hepatic } \\
\text { hepato-neurologic }\end{array} \\
\text { hen }\end{array}$ & $\begin{array}{l}\text { all presentations: } \\
2 / 15(13) \text { vs. } 0 / 1(0)\end{array}$ & & $\begin{array}{l}0 / 1(0) \text { vs. } 0 / 0(0) \\
0 / 10(0) \text { vs. } 1 / 1(100) \\
0 / 4(0) \text { vs. } 0 / 0(0) \\
\end{array}$ & $\begin{array}{l}0 / 1(0) \text { vs. } 0 / 0(0) \\
2 / 10(20) \text { vs. } 1 / 1(100) \\
1 / 4(25) \text { vs. } 0 / 0(0)\end{array}$ & & $\begin{array}{l}0 / 1(0) \text { vs. } 0 / 0(0) \\
2 / 10(20)[2 \mathrm{SE}] \text { vs. } 0 / 1(0) \\
1 / 4(25)[1 \mathrm{SE}] \text { vs. } 0 / 0(0)\end{array}$ \\
\hline Weiss, 2013† & $\begin{array}{r}\text { presymptomatic } \\
\text { hepatic } \\
\text { hepato-neurologic } \\
\text { neurologic }\end{array}$ & & $\begin{array}{l}32 / 48(67) \text { vs. } 2 / 2(100) \\
88 / 150(59) \text { vs. } 14 / 20(70) \\
12 / 31(39) \text { vs. } 6 / 7(86) \\
32 / 66(48) \text { vs. } 7 / 9(78)\end{array}$ & & $\begin{array}{l}\text { all presentations: } \\
182 / 295 \text { (62) vs. } 9 / 38 \text { (24) }\end{array}$ & $\begin{array}{l}\text { NA } \\
\text { NA } \\
8 / 97(8) \text { vs. } 5 / 16(31)\end{array}$ & 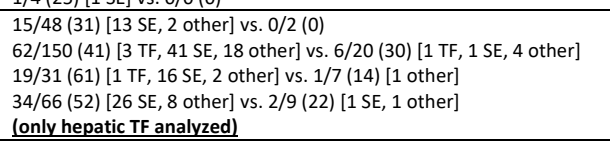 \\
\hline \multicolumn{8}{|c|}{ D-Penicillamine (+ Zn-gluconate) versus succimer (+ Zn-gluconate): Number of patients with event / Total number of patients (\%) } \\
\hline Ren, 1998 & $\begin{array}{r}\begin{array}{r}\text { presymptomatic } \\
\text { hepatic } \\
\text { neurologic }\end{array} \\
\end{array}$ & & $\begin{array}{l}\text { all presentations: } \\
35 / 60(58) \text { vs. } 49 / 60(82)\end{array}$ & & $\begin{array}{l}\text { all presentations: } \\
22 / 60(37) \text { vs. } 9 / 60(15)\end{array}$ & & $\begin{array}{l}\text { all presentations: } \\
25 / 60(42)[25 \mathrm{TF}] \text { vs. } 11 / 60(18)[11 \mathrm{TF}\end{array}$ \\
\hline \multicolumn{8}{|c|}{ Trientine (+ Zn-acetate) versus tetrathiomolybdate (+ Zn-acetate): Number of patients with event / Total number of patients (\%) } \\
\hline $\begin{array}{l}\text { Brewer, } 2006 \\
\text { (Brewer, } \\
\text { 2008) }\end{array}$ & neurologic & $\begin{array}{l}0 / 23(0) \text { vs. } 0 / 25(0) \\
(6 \text { pat died under } \mathrm{Zn} \\
\text { maintenance; FU 6-22 mo) }\end{array}$ & & & $1 / 23(4)$ vs. $7 / 25(28)$ & $6 / 23(26)$ vs. $1 / 25(4)$ & \\
\hline
\end{tabular}

† outcome data unpublished; available on request;
END, early neurologic deterioration; FU, follow-up; NA, not applicable; NR, not reported; OLT, orthotopic liver transplantation; pat, patient; SE, side effect; TF treatment failure; Zn, zinc 
Table S4: First choice recommendations by study authors comparing chelator (DPen, trientine) and $\mathrm{Zn}$ treatments

\begin{tabular}{|c|c|c|c|c|c|c|c|c|}
\hline \multirow{2}{*}{$\begin{array}{l}\text { Patients } \\
\text { Therapy }\end{array}$} & \multicolumn{2}{|c|}{ Hepatict } & \multicolumn{2}{|c|}{ Neurologict } & \multicolumn{2}{|c|}{ Presymptomatict } & \multicolumn{2}{|c|}{ Pediatric } \\
\hline & I & $\mathbf{M}$ & I & $\mathbf{M}$ & I & $\mathbf{M}$ & I & M \\
\hline$A A S L D^{145}$ & Chelator & $\begin{array}{c}\text { Chelator } \\
\text { or } \mathrm{Zn}\end{array}$ & Chelator & $\begin{array}{c}\text { Chelator } \\
\text { or } \mathrm{Zn}\end{array}$ & $\begin{array}{c}\text { Chelator } \\
\text { or } \mathrm{Zn}\end{array}$ & $\begin{array}{c}\text { Chelator } \\
\text { or } \mathrm{Zn}\end{array}$ & - & - \\
\hline$E A S L^{146}$ & Chelator & - & $\begin{array}{c}\text { Chelator } \\
\text { (or Zn) }\end{array}$ & $\begin{array}{c}\text { Chelator } \\
\text { or } \mathrm{Zn}\end{array}$ & $\begin{array}{c}\text { Chelator } \\
\text { or } \mathrm{Zn}\end{array}$ & $\begin{array}{c}\text { Chelator } \\
\text { or } \mathrm{Zn}\end{array}$ & - & - \\
\hline$I N A S L^{147}$ & Chelator & $\begin{array}{c}\text { Chelator } \\
\text { or } \mathrm{Zn}\end{array}$ & $\begin{array}{c}\text { Chelator } \\
\text { or } \mathrm{Zn}\end{array}$ & $\begin{array}{c}\text { Chelator } \\
\text { or } \mathrm{Zn}\end{array}$ & $\begin{array}{c}\text { Chelator } \\
\text { or } \mathrm{Zn}\end{array}$ & $\begin{array}{c}\text { Chelator } \\
\text { or } \mathrm{Zn}\end{array}$ & - & - \\
\hline ESPGHAN ${ }^{148}$ & - & - & - & - & - & - & $\begin{array}{c}\text { Chelator } \\
\text { or } \mathrm{Zn} \neq\end{array}$ & $\mathrm{Zn}$ \\
\hline
\end{tabular}

Czlonkowska, $1996^{149}$

\begin{tabular}{ll|l}
- & - & Zn
\end{tabular}

\begin{tabular}{ll|l}
$Z n$ & - \\
$Z n$
\end{tabular}

ng-term observation of a relatively large group of patients permits us to consider $\mathrm{Zn}$ as the drug of first choice for the initiation of treatment in patients with neurological and preclinical forms of WD. To be able to answer the question as to whether Zn or D-P is more effective in the hepatic form of the disease or for specific neurological signs, more extensive observation is required, (...)"

Medici, $2006^{150}$

DPen

$\mathrm{Zn}$

$\mathrm{Zn}$

"D-PCA is effective in treating WD without related neurologic symptoms, whereas zinc could effectively replace D-PCA in the event of side effects and we suggest it as first-line therapy in cases with neurologic symptoms, in presymptomatic subjects and during pregnancy."

Merle, $2007^{15}$

\section{Trientine}

$$
\text { or } \mathrm{Zn}
$$

"(...) in our opinion, D-penicillamine should not be the drug of choice for patients with neurological symptoms."

Bruha, $2011^{152}$ DPen

$\mathrm{Zn}$

"Our study confirms the good efficacy of zinc salts in patients with neurological WD, and of D penicillamine in those patients with the hepatic form of WD (...)" 


\begin{tabular}{|c|c|c|c|c|c|c|c|c|}
\hline Weiss, $2011^{153}$ & chelator & - & $\begin{array}{l}\text { Chelator } \\
\text { or Zn }\end{array}$ & - & $\begin{array}{c}\text { Chelator } \\
\text { or } \mathrm{Zn}\end{array}$ & - & - & - \\
\hline \multirow{3}{*}{ Rodriguez, 2012 154} & \multicolumn{8}{|c|}{$\begin{array}{l}\text { "In conclusion, the primary role of zinc monotherapy may remain as a medical treatment alternative for } \\
\text { asymptomatic or neurologically affected patients." }\end{array}$} \\
\hline & DPen & $\begin{array}{l}\text { DPen or } \\
\text { Zn }\end{array}$ & DPen & $\begin{array}{l}\text { DPen or } \\
\text { Zn }\end{array}$ & $\begin{array}{l}\text { DPen or } \\
\quad \mathrm{Zn}\end{array}$ & $\begin{array}{l}\text { DPen or } \\
\quad \mathrm{Zn}\end{array}$ & - & - \\
\hline & \multicolumn{8}{|c|}{$\begin{array}{l}\text { "In our series, d-penicillamine was the drug mostly used, particularly in those who were symptomatic at } \\
\text { diagnosis. In patients at pre-symptomatic stages or on maintenance therapy, chelators or Zn are } \\
\text { potential alternatives." }\end{array}$} \\
\hline \multirow[t]{3}{*}{ Czlonkowska, 2014 } & $\begin{array}{l}\text { DPen or } \\
\text { Zn }\end{array}$ & - & $\mathrm{Zn}$ & - & $\begin{array}{l}\text { DPen or } \\
\text { Zn }\end{array}$ & - & - & - \\
\hline & \multicolumn{8}{|c|}{$\begin{array}{l}\text { "Adjusted analysis showed that neurological WD patients treated with first-line DPA may be potentially } \\
\text { more prone to experience early worsening. (...) Therefore, because of their different and slower } \\
\text { mechanism of action, zinc salts may seem safer in patients with neurological WD. (...) ZS may } \\
\text { be considered a reasonable alternative to DPA as first-line therapy in all WD patients, not only in those } \\
\text { less affected or asymptomatic." }\end{array}$} \\
\hline & - & - & - & - & - & - & $\mathrm{Zn}$ & $\mathrm{Zn}$ \\
\hline Ranucci, $2014^{156}$ & \multicolumn{8}{|c|}{$\begin{array}{l}\text { "Zinc monotherapy is effective in controlling WD-related liver disease both as first-line and as } \\
\text { maintenance treatment in patients with mild liver disease diagnosed in childhood." }\end{array}$} \\
\hline
\end{tabular}

† All ages; ¥ Chelator for hepatic presentation, Zn for presymptomatic presentation; AASLD, American Association for the Study of Liver Diseases; EASL, European Association for the Study of the Liver; ESPGHAN, European Society for Paediatric Gastroenterology, Hepatology and Nutrition; INASL, Indian National Association for Study of the Liver; I, initial; M, maintenance 


\section{Table S5: Statements on lack of correlation between elevated serum transaminases and liver disease}

\begin{tabular}{|c|c|}
\hline & Wording \\
\hline Iorio, $2004^{157}$ & $\begin{array}{l}\text { "No significant difference was found in basal histologic lesions between patients with persistent hypertransaminasemia and } \\
\text { patients who normalized ALT on therapy." } \\
\text { "Interestingly, despite longstanding hypertransaminasemia, no patient showed worsening of the liver disease or developed } \\
\text { other Wilson's disease-related symptoms." }\end{array}$ \\
\hline Medici, $2006^{150}$ & $\begin{array}{l}\text { "Twenty percent of our patients had longstanding mild hypertransaminasemia unresponsive to either D-PCA or zinc, but no } \\
\text { sign of any progression of their liver disease." }\end{array}$ \\
\hline Weiss, $2011^{153}$ & $\begin{array}{l}\text { "In patients with nonresponse to zinc therapy, an increase in liver enzyme levels was noted (Figure 2) compared with zinc } \\
\text { responders. (...) The comparison of the time course of other laboratory values (alkaline phosphatase, choline esterase, } \\
\text { international normalized ratio, bilirubin, serum copper, ceruloplasmin, non-ceruloplasmin-bound copper) revealed no } \\
\text { statistically significant differences between the responder and nonresponder groups at any time point (data not shown)." }\end{array}$ \\
\hline Sini, $2013^{159}$ & $\begin{array}{l}\text { "The need to carry out a follow-up of the histology features is further supported by the fact that in our study, the clinical } \\
\text { course and histopathologic evolution of liver disease did not correlate with the laboratory data examined. (...) This is why } \\
\text { biochemical parameters are not sufficient to assess the effectiveness of medical therapy on the evolution of liver disease, } \\
\text { and we suggest the need to carry out a clinical follow-up and periodic histologic evaluation." }\end{array}$ \\
\hline
\end{tabular}


Figure S1: Effect of DPen versus Zn treatment on side effects. Summary odds ratio derived from betabinomial model (BBIN); box sizes reflect the weights of the fixed-effect inverse variance model (IV).

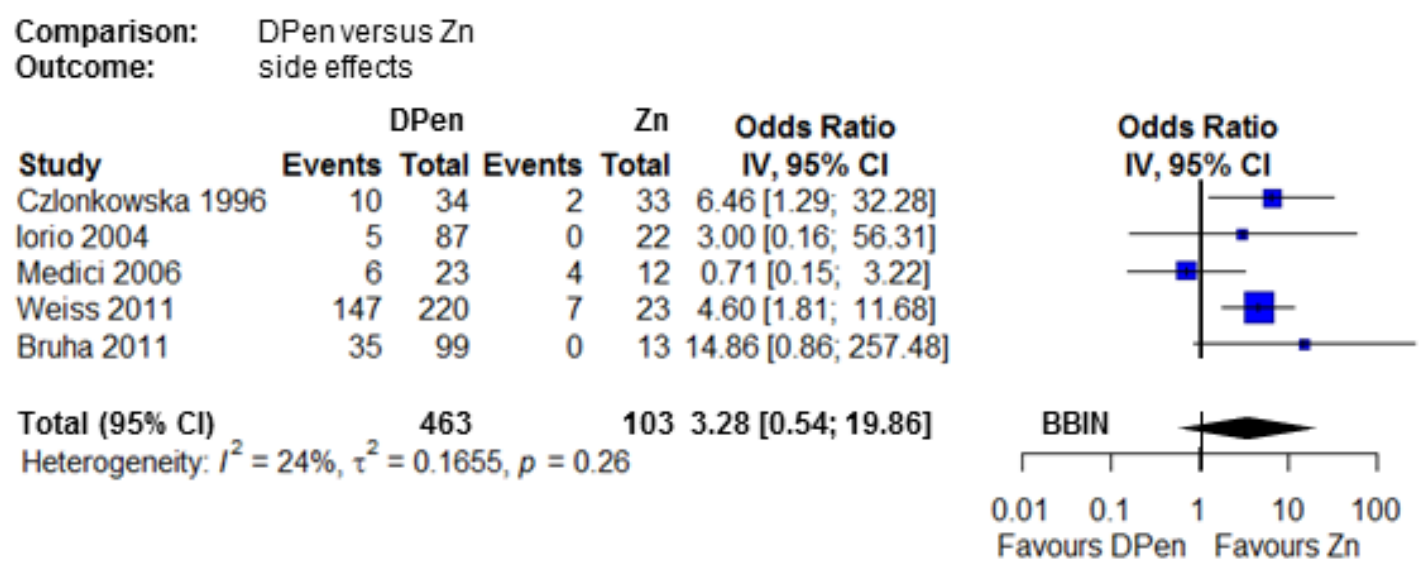

Figure S2: Effect of DPen versus $\mathrm{Zn}$ treatment on neurologic deterioration. Summary odds ratio derived from beta-binomial model (BBIN); box sizes reflect the weights of the fixed-effect inverse variance model (IV). Note that only Medici 2006 and Czlonkowska 2014 specifically reported on early neurologic deterioration.

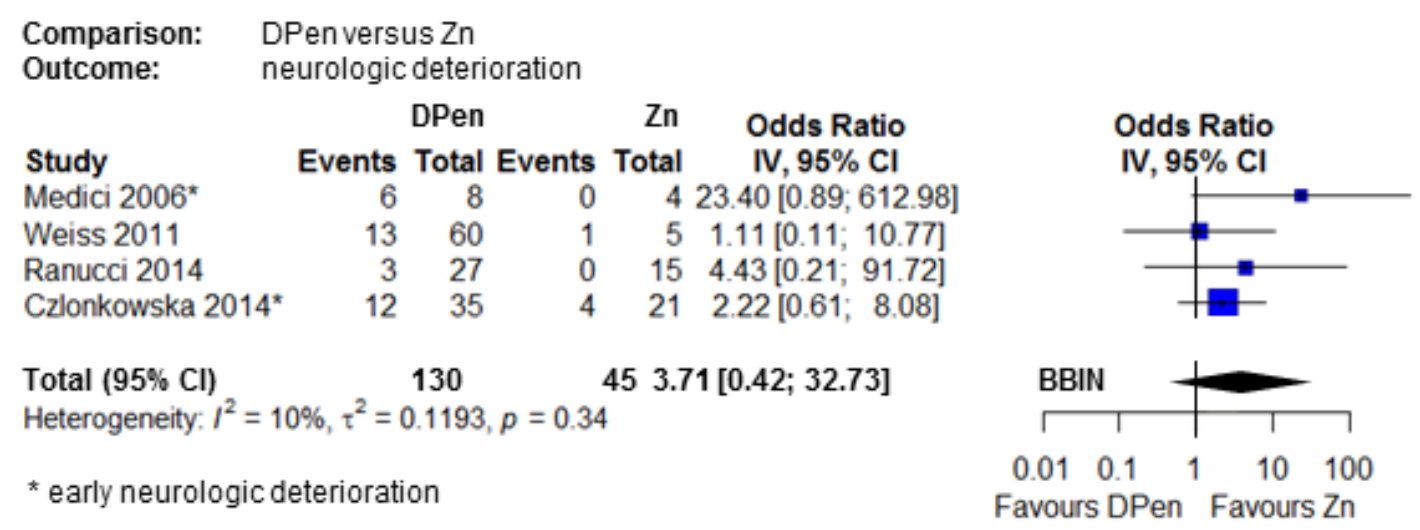


Figure S3: Effect of DPen versus $\mathrm{Zn}$ treatment on treatment discontinuation. Performed with inversevariance (IV) random effects meta-analysis using the Paule-Mandel between study heterogeneity estimator with modified Hartung-Knapp confidence intervals.

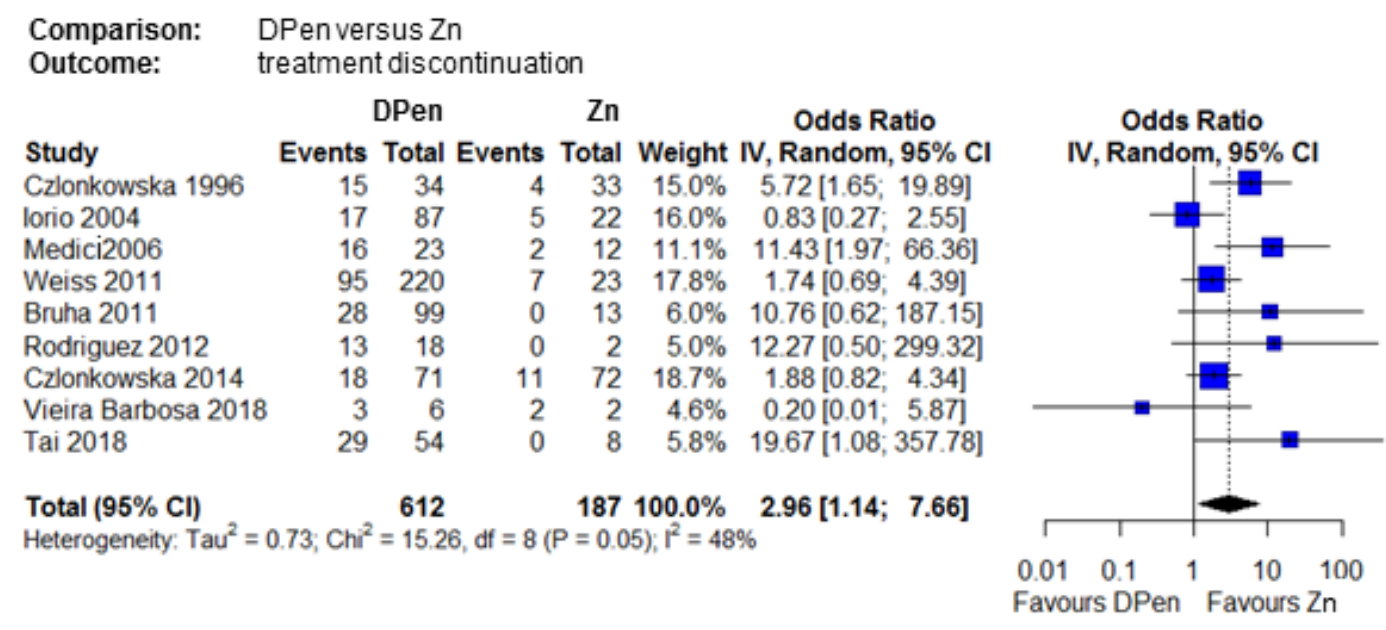


1. Abdel Ghaffar TY, Elsayed SM, Elnaghy S, Shadeed A, Elsobky ES, Schmidt H. Phenotypic and genetic characterization of a cohort of pediatric Wilson disease patients. BMC Pediatr 2011; 11: 56.

2. Aggarwal A, Bhatt M. Complete neurological recovery in wilson disease: Experience with 100 consecutive patients seen from 2005-2013. Neurology Conference: 66th American Academy of Neurology Annual Meeting, AAN 2014; 82(10 SUPPL. 1).

3. Aggarwal A, Bhatt M. Neurological worsening in patients undergoing treatment for Wilson's disease: Frequency, causes and outcomes. Mov Disord 2017; 32: 409-10.

4. Al Fadda M, Al Quaiz M, Al Ashgar $\mathrm{H}$, et al. Wilson disease in 71 patients followed for over two decades in a tertiary center in Saudi Arabia: a retrospective review. Ann Saudi Med 2012; 32(6): 623-9.

5. Alam S, Khanna R, Sood V. Outcome of hepatic Wilson's disease at 6 months from diagnosis: Response to combination of D-Pencillamine and zinc therapy in a tertiary care centre in India. J Inherit Metab Dis 2013; 1): S340.

6. Aposhian HV. Penicillamine and analogous chelating agents. Ann N Y Acad Sci 1971; 179: 481-

6.

7. Arnon R, Calderon JF, Schilsky M, Emre S, Shneider BL. Wilson disease in children: serum aminotransferases and urinary copper on triethylene tetramine dihydrochloride (trientine) treatment. J Pediatr Gastroenterol Nutr 2007; 44(5): 596-602.

8. Askari FK, Greenson J, Dick RD, Johnson VD, Brewer GJ. Treatment of Wilson's disease with zinc. XVIII. Initial treatment of the hepatic decompensation presentation with trientine and zinc. J Lab Clin Med 2003; 142(6): 385-90.

9. Avan A, Azarpazhooh MR, Hoogenraad TU. Effective shift from traditional chelation therapy to evidence based zinc monotherapy in four patients with Wilson's disease and parkinsonism. Mov Disord 2013; 28: S352-S53.

10. Avan A, Azarpazhooh MR, Hoogenraad TU. Zinc therapy reverses neurodegeneration in wilson's disease patients with parkinsonism. Neurodegenerative Diseases 2015; 15: 1941.

11. Avinashi V, Ling S. Wilson disease in children; A six-year experience, 2001-2008. Canadian Journal of Gastroenterology Conference: Canadian Digestive Diseases Week 2009; 23(no pagination).

12. Bachmann $\mathrm{H}$, Lossner J, Kuhn HJ, et al. Long-term care and management of Wilson's disease in the GDR. Eur Neurol 1989; 29(6): 301-05.

13. Baeg JY, Jang ES, Ki MR, et al. A Nationwide, population-based epidemiology and disease burden of wilson 's disease in South Korea in 2009-2013. Hepatology 2015; 62: 1237A-38A.

14. Bagchi M, Das SK. Wilson's disease: Follow-up studies in a cohort of 135 neuro- Wilson's patients for more than a decade. Mov Disord 2012; 27: S72.

15. Barbosa ER, Scaff M, Canelas HM. Hepatolenticular degeneration: Analysis of neurological manifestations under treatment in 76 patients. [Portuguese]. Arq Neuropsiquiatr 1991; 49(4): 399404.

16. Beinhardt S, Leiss W, Graziadei I, et al. Long-term outcome of a large patient cohort with Wilson disease in Austria. Hepatology 2012; 56: 827A.

17. Bem RS, Muzzillo DA, Deguti MM, Barbosa ER, Werneck LC, Teive HA. Wilson's disease in southern Brazil: a 40-year follow-up study. Clinics (Sao Paulo, Brazil) 2011; 66(3): 411-6.

18. Berenguer M. Significant heterogeneity in the diagnosis and management of wilson disease (WD): Results from a large spanish registry. Hepatology 2017; 66 (Supplement 1): 443A-44A.

19. Bono W, Moutie O, Benomar A, et al. Wilson's disease. Clinical presentation, treatment and evolution in 21 cases. [French]. Rev Med Interne 2002; 23(5): 419-31.

20. Brewer GJ. Practical recommendations and new therapies for Wilson's disease. Drugs 1995; 50(2): 240-9. 
21. Brewer GJ, Johnson V, Dick RD, Kluin KJ, Fink JK, Brunberg JA. Treatment of Wilson disease with ammonium tetrathiomolybdate. II. Initial therapy in 33 neurologically affected patients and follow-up with zinc therapy. Arch Neurol 1996; 53(10): 1017-25.

22. Brewer G, Johnson V, Kaplan J. Treatment of Wilson's disease with zinc: xIV. Studies of the effect of zinc on lymphocyte function. J Lab Clin Med 1997; 129(6): 649-52.

23. Brewer GJ, Hedera P, Kluin KJ, et al. Treatment of Wilson disease with ammonium tetrathiomolybdate: III. Initial therapy in a total of 55 neurologically affected patients and follow-up with zinc therapy. Arch Neurol 2003; 60(3): 379-85.

24. Brewer G, Askari F, Lorincz M, et al. Treatment of Wilson disease with ammonium tetrathiomolybdate: iV. Comparison of tetrathiomolybdate and trientine in a double-blind study of treatment of the neurologic presentation of Wilson disease. Arch Neurol 2006; 63(4): 521-27.

25. Brewer G, Askari F, Lorincz M, et al. Tetrathiomolybdate versus trientine in the initial treatment of neurologic Wilson's disease. Progress in neurotherapeutics and neuropsychopharmacology 2008; 3(1): 153-65.

26. Burke JF, Dayalu P, Nan B, Askari F, Brewer GJ, Lorincz MT. Prognostic significance of neurologic examination findings in Wilson disease. Parkinsonism Relat Disord 2011; 17(7): 551-6.

27. Chu NS, Hung TP. Geographic variations in Wilson's disease. J Neurol Sci 1993; 117(1-2): 1-7.

28. Cossack CT, Bouquet J. The treatment of Wilson's disease in paediatrics: Oral zinc therapy versus penicillamine. Acta Pharmacol Toxicol (Copenh) 1986; 59(SUPPL. 7): 514-17.

29. Czlonkowska A, Maselbas W, Chabik G, Czlonkowski A. Persistence with anti-copper treatment among patients with Wilson disease. J Neurol 2010; 257: S14.

30. Czlonkowska A, Litwin T, Karlinski M, Czerska M. D-penicillamine versus zinc sulfate as firstline therapy for Wilson's disease. J Neurol Sci 2013; 333: e140.

31. Czlonkowska A, Litwin T, Karlinski M, Dziezyc K. Early neurological worsening in wilson's disease patients. Neurology Conference: 67th American Academy of Neurology Annual Meeting, AAN 2015; 84(no pagination).

32. Da Costa Mdo D, Spitz M, Bacheschi LA, Leite CC, Lucato LT, Barbosa ER. Wilson's disease: two treatment modalities. Correlations to pretreatment and posttreatment brain MRI. Neuroradiology 2009; 51(10): 627-33.

33. Dastych M, Prochazkova D, Pokorny A, Zdrazil L. Copper and zinc in the serum, urine, and hair of patients with Wilson's disease treated with penicillamine and zinc. Biol Trace Elem Res 2010; 133(3): 265-9.

34. De Sousa BRRM, Antunes H. The first study of Wilson's disease prevalence in a Portuguese population. J Pediatr Gastroenterol Nutr 2017; 64: 637.

35. Deiss A, Lynch RE, Lee GR, Cartwright GE. Long-term therapy of Wilson's disease. Ann Intern Med 1971; 75(1): 57-65.

36. Demir K, Soyer OM, Karaca C, Besisik F, Kaymakoglu S. The course of pregnancy in wilson's disease-one center, 20 years' experience. Gastroenterology 2014; 1): S-1009.

37. Denny-Brown D. Hepatolenticular Degeneration (Wilson's Disease). Two Different Components. N Engl J Med 1964; 270: 1149-56.

38. Dubbioso R, Ranucci G, Esposito M, et al. Subclinical neurological involvement does not develop if Wilson's disease is treated early. Parkinsonism Relat Disord 2016; 24: 15-9.

39. Dziezyc K, Karlinski M, Litwin T, Czlonkowska A. Compliant treatment with anti-copper agents prevents clinically overt Wilson's disease in pre-symptomatic patients. Eur J Neurol 2014; 21(2): 3327.

40. El Machkour M, Babakhouya A, El Ouali O, et al. Neuro-Wilson disease - about seven cases and review of the literature. African Journal of Neurological Sciences 2011; 30(1).

41. El-Karaksy H, Fahmy M, El-Raziky MS, et al. A clinical study of Wilson's disease: The experience of a single Egyptian Paediatric Hepatology Unit. Arab Journal of Gastroenterology 2011; 12(3): 125-30.

42. Engelbrecht V, Schlaug G, Hefter H, Kahn T, Modder U. MRI of the brain in Wilson disease: T2 signal loss under therapy. J Comput Assist Tomogr 1995; 19(4): 635-8. 
43. Esposito M, Dubbioso R, Manganelli F, et al. Current status of Wilson disease: Does early treatment protect from nervous system impairment? Mov Disord 2013; 28: S352.

44. Estevo AD, Carvalho MJ, Machado AaC, Barbosa ER. Behavior of speech in Wilson's disease. Mov Disord 2012; 27: S73.

45. Fadda MA, Helmy A, Benmousa AH, et al. Wilson's disease: Experience with 71 patients followed for two decades in a Tertiary Centre in Saudi Arabia. Gastroenterology 2009; 1): A844.

46. Gill HH, Shankaran K, Desai HG. Wilson's disease: varied hepatic presentations. Indian J Gastroenterol 1994; 13(3): 95-8.

47. Girardot-Tinant N, Trocello JM, Ruano E, Pelosse M, Woimant F. Wilson disease in france: Follow-up of a cohort of 395 patients. Neuroepidemiology 2012; 39 (3-4): 210.

48. Goldstein NP, Randall RV, Gross JB, Mcguckin WF. Copper Balance Studies in Wilson's Disease (Hepatolenticular Degeneration). Observations on the Effect of Penicillamine, Carbo-Resin and Potassium Sulfide. Trans Am Neurol Assoc 1963; 88: 221-2.

49. Goldstein NP, Randall RV, Gross JB, Mcguckin WF. Copper Balance Studies in Wilson's Disease; Observations on the Effect of Penicillamine, Carbacrylamine Resins, and Potassium Sulfide. Arch Neurol 1965; 12: 456-62.

50. Gromadzka G, Karpinska A, Przybylkowski A, et al. Treatment with D-penicillamine or zinc sulphate affects copper metabolism and improves but not normalizes antioxidant capacity parameters in Wilson disease.[Erratum appears in Biometals. 2014 Feb;27(1):217 Note: Grazyna, Gromadzka [corrected to Gromadzka, Grazyna]; Agata, Karpinska [corrected to Karpinska, Agata]; Adam, Przybylkowski [corrected to Przybylkowski, Adam]; Tomasz, Litwin [corrected to Litwin, Tomasz]; Agata, Wierzchowska-Ciok [corrected to Wierzchowska-Ciok, Agata]; Karolina, Dziezyc [corrected to Dziezyc, Karolina]; Grzegorz, Chabik [corrected to Chabik, Grzegorz]; Anna, Czlonkowska [corrected to Czlonkowska, Anna]]. Biometals 2014; 27(1): 207-15.

51. Gupta P, Choksi M, Goel A, et al. Maintenance Zinc therapy after initial Penicillamine chelation to treat symptomatic hepatic Wilson's disease in resource constrained setting. J Gastroenterol Hepatol 2017; 32 (Supplement 3): 154.

52. Gupta P, Choksi M, Goel A, et al. Maintenance zinc therapy after initial penicillamine chelation to treat symptomatic hepatic Wilson's disease in resource constrained setting. Indian J Gastroenterol 2018; 37(1): 31-38.

53. Harders $\mathrm{H}$, Cohnen E. Preparation of and clinical experiences with trien for the treatment of Wilson's disease in absolute intolerance of D-penicillamine. Proc R Soc Med 1977; 70 Suppl 3: 10-2. 54. Hefter $\mathrm{H}$, Tezayak $\mathrm{O}$, Rosenthal $\mathrm{D}$. Long-term outcome of neurological Wilson's disease. Parkinsonism and Related Disorders 2018; 49: 48-53.

55. Hill GM, Brewer GJ, Juni JE, Prasad AS, Dick RD. Treatment of Wilson's disease with zinc. II. Validation of oral 64copper with copper balance. Am J Med Sci 1986; 292(6): 344-9.

56. Hoogenraad TU, Van Hattum J, Van Den Hamer CJ. Management of Wilson's disease with zinc sulphate. Experience in a series of 27 patients. J Neurol Sci 1987; 77(2-3): 137-46.

57. Hsia Y, Combs J, Hook L, Brandt I. Hepatolenticular degeneration: the comparative effectiveness of d-penicillamine, potassium sulfide, and diethylditbiocarbamate as decoppering agents. J Pediatr 1966; 68(6): 921-26.

58. Hui J, Chiang GPK, Yuen YP, Law ELK, Sun KKM, Tang NLS. Ten Chinese paediatric patients with Wilsons disease. J Inherit Metab Dis 2011; 34: S123.

59. Idrissi ML, Babakhoya A, Khabbache $K$, et al. [Wilson's disease in the child: apropos of 20 cases]. [French]. The Pan African medical journal 2013; 14: 6.

60. Jablonska-Kaszewska I, Drobinska-Jurowiecka A, Dabrowska E, Trocha H. Results of treatment of Wilson's disease--own observations. Med Sci Monit 2003; 9 Suppl 3: 9-14.

61. Janczyk W, Dadalski M, Schmidt H, Houwen R, Socha P. Zinc vs. d-penicillamine treatment in children with Wilson disease and liver presentation. Experimental and Clinical Hepatology 2009; 5 (2): 21.

62. Janczyk W, Pronicki M, Grajkowska W, et al. Predictors of liver steatosis and fibrosis measured by Fibroscan in children with Wilson's disease. J Pediatr Gastroenterol Nutr 2016; 62: 609. 
63. Janczyk W, Dadalski M, Socha P. Follow-up of liver steatosis and fibrosis in children with Wilson's disease using transient elastography (Fibroscan). J Pediatr Gastroenterol Nutr 2017; 64: 672. 64. Kalita J, Kumar V, Chandra S, Kumar B, Misra UK. Worsening of Wilson disease following penicillamine therapy. Eur Neurol 2014; 71(3-4): 126-31.

65. Kalita J, Ranjan A, Misra UK. Oromandibular Dystonia in Wilson's Disease. Movement Disorders Clinical Practice 2015; 2(3): 253-59.

66. Kalra V, Khurana D, Mittal R. Wilson's disease--early onset and lessons from a pediatric cohort in India. Indian Pediatr 2000; 37(6): 595-601.

67. Kazemi K, Geramizadeh B, Nikeghbalian S, et al. Effect of D-penicillamine on liver fibrosis and inflammation in Wilson disease. Experimental and clinical transplantation : official journal of the Middle East Society for Organ Transplantation 2008; 6(4): 261-63.

68. Kleine RT, Mendes R, Pugliese R, Miura I, Danesi V, Porta G. Wilson's disease: an analysis of 28 Brazilian children. Clinics (Sao Paulo, Brazil) 2012; 67(3): 231-5.

69. Kondou $\mathrm{H}$, Hasegawa $\mathrm{Y}$, Tachibana $\mathrm{M}$, et al. Utility of zinc acetate treatment in 15 patients with childhood onset wilson disease: A single center experience. J Trace Elem Med Biol 2013; 27: 32.

70. Kucinskas L, Jeroch J, Vitkauskiene A, et al. High frequency of the c.3207C>A (p.H1069Q) mutation in ATP7B gene of Lithuanian patients with hepatic presentation of Wilson's disease. World J Gastroenterol 2008; 14(38): 5876-9.

71. Kumar A, Kumar R, Kumar U, Sharan A, Shahi SK. A retrospective study about characteristics of Wilson's disease at tertiary care institute of North India. Mov Disord 2010; 25: S260.

72. Kumar N, Joshi D. Clinical, biochemical and radiological profile of Wilson's disease and effect of treatment. J Neurol 2012; 1): S31-S32.

73. Kumar N, Joshi D. Epilepsy in Wilson's disease (WD). Mov Disord 2012; 27: S73-S74.

74. Kunath B, Reuner U. Diagnosis and treatment of Wilson's disease experience of 38 years therapy in a spezialised out-patients clinic. [German]. Aktuelle Neurologie 2003; 30(1): 18-26.

75. Lapeyre D, Gottrand F, Debray D, et al. Efficacy and tolerance of zinc in the treatment of wilson disease. J Pediatr Gastroenterol Nutr 2010; 50: E154-E55.

76. Lingam S, Wilson J, Nazer H, Mowat AP. Neurological abnormalities in Wilson's disease are reversible. Neuropediatrics 1987; 18(1): 11-2.

77. Lossner J, Storch W, Bachmann H, Biesold D, Kuhn HJ. [Wilson's disease in the German Democratic Republic. III. Diagnosis and therapy]. Z Gesamte Inn Med 1980; 35(4): 161-6.

78. Manolaki N, Nikolopoulou G, Daikos GL, et al. Wilson disease in children: analysis of 57 cases. J Pediatr Gastroenterol Nutr 2009; 48(1): 72-7.

79. Medici V, Di Leo V, Lamboglia F, et al. Effect of penicillamine and zinc on iron metabolism in Wilson's disease. Scand J Gastroenterol 2007; 42(12): 1495-500.

80. Mercier-Jacquier M, Bronowicki JP, Raabe JJ, Jacquier A, Kaminsky P. Wilson's disease in adult. [French]. Rev Med Interne 2011; 32(6): 341-46.

81. Moores A, Fox S, Hirschfield GM. The Toronto Western Hospital Wilson's disease study: Perspectives from an adult urban ambulatory centre. Hepatology 2010; 52: 498A.

82. Moores A, Hirschfield G, Lang T, Fox SH. Wilson's disease: A Canadian perspective on the presentation and clinical outcomes in an adult ambulatory setting. Mov Disord 2011; 26: S336.

83. Moores A, Fox SH, Lang AE, Hirschfield GM. Wilson disease: Canadian perspectives on presentation and outcomes from an adult ambulatory setting. Can J Gastroenterol 2012; 26(6): 33339.

84. Ogihara $\mathrm{H}$, Ogihara T, Miki M, Yasuda H, Mino M. Plasma copper and antioxidant status in Wilson's disease. Pediatr Res 1995; 37(2): 219-26.

85. Osborn SB, Walshe JM. Effects of penicillamine and dimercaprol on turnover of copper in patients with Wilson's disease. Lancet 1958; 1(7011): 70-3.

86. Park RH, Mccabe P, Fell GS, Russell RI. Wilson's disease in Scotland. Gut 1991; 32(12): 1541-5.

87. Parkash O, Ayub A, Jafri W, Alishah H, Hamid S. Presentation of Wilson's disease in Pakistan: A tertiary care hospital experience in Karachi Pakistan. J Gastroenterol Hepatol 2012; 27: 210-11. 
88. Parkash O, Ayub A, Jafri W, Alsihah SH, Hamid S. Presentation of wilsons disease in Pakistan: Is it different from the rest of world? Hepatol Int 2012; 6 (1): 258.

89. Pellecchia MT, Criscuolo C, Longo K, Campanella G, Filla A, Barone P. Clinical presentation and treatment of Wilson's disease: a single-centre experience. Eur Neurol 2003; 50(1): 48-52.

90. Pfeiffenberger J, Lohse CM, Gotthardt D, et al. Long-term evaluation of urinary copper excretion and non-caeruloplasmin associated copper in Wilson disease patients under medical treatment. J Inherit Metab Dis 2018: 1-9.

91. Pietrobattista A, Candusso M, Alterio A, et al. Wilson's diseases: Single center's 1 year overall experience. Dig Liver Dis 2010; 42: S374.

92. Poujois A, Tuppin P, Samson S, Chaine P, Girardot-Tinant N, Woimant F. First epidemiologic study of Wilson's disease in France. Eur J Neurol 2016; 23: 554.

93. Poujois A, Woimant F, Samson S, Chaine P, Girardot-Tinant N, Tuppin P. Characteristics and prevalence of Wilson's disease: A 2013 observational population-based study in France. Clin Res Hepatol Gastroenterol 2018; 42(1): 57-63.

94. Ramachandiran N, Alhabsi A, Al-Asmi A, et al. Wilson's disease in Oman: A study of neurological manifestations and diagnostic delay from a University Teaching Hospital. Eur J Neurol 2012; 19: 681.

95. Ranucci G, Di Dato F, Della Corte C, Vajro P, lorio R. Long-term zinc therapy in wilson disease children with mild liver disease. J Pediatr Gastroenterol Nutr 2011; 52: E183.

96. Ranucci G, Di Dato F, Puoti G, Liccardo D, Tufano M, lorio R. Long term zinc therapy inwilson disease children with mild liver disease. Dig Liver Dis 2012; 44: S102.

97. Ranucci G, Di Dato F, Tufano M, et al. Long term follow-up of wilson disease patients diagnosed in childhood: Reasons for treatment changes. Dig Liver Dis 2013; 45: e273.

98. Ranucci G, Dubbioso R, Esposito M, et al. Subclinical neurological involvement does not develop if Wilson's disease is treated early. J Pediatr Gastroenterol Nutr 2016; 62: 624.

99. Ras J, Houwen R, Linn FH, Van Erpecum KJ. Symptomatic Wilson disease during longterm zinc maintenance monotherapy after initial penicillamine decoppering: Experience in 30 patients.

Hepatology 2010; 52: 495A.

100. Richmond J, Rosenoer VM, Tompsett SL, Draper I, Simpson JA. Hepato-Lenticular Degeneration (Wilson's Disease) Treated by Penicillamine. Brain 1964; 87: 619-38.

101. Rodrigo Agudo JL, Valdes Mas M, Vargas Acosta AM, et al. Clinical presentation, diagnosis, and long-term outcome of 29 patients with Wilson's disease. [Spanish]. Rev Esp Enferm Dig 2008; 100(8): 456-61.

102. Saito H, Watanabe K, Sahara M, Mochizuki R, Edo K, Ohyama Y. Triethylene-tetramine (trien) therapy for Wilson's disease. Tohoku J Exp Med 1991; 164(1): 29-35.

103. Sanchez CS, Campdera JaG, Perez JLM, Robert LBH, Sanchez MIG, Gonzalez AS. Wilson's disease. Different forms of onset. [Spanish]. Acta Pediatr Esp 1997; 55(5): 204-09.

104. Santiago R, Gottrand F, Debray D, et al. Zinc Therapy for Wilson Disease in Children in French Pediatric Centers. J Pediatr Gastroenterol Nutr 2015; 61(6): 613-8.

105. Santos Silva EE, Sarles J, Buts JP, Sokal EM. Successful medical treatment of severely decompensated Wilson disease. J Pediatr 1996; 128(2): 285-7.

106. Sarapura E, Ramirez-Quinones J, Cornejo-Olivas M, Torres L. Clinical features of Wilson's disease in Peru: Review of eight cases. Movement Disorders Conference: 1st Pan American Parkinson's Disease and Movement Disorders Congress United States 2017; 32(no pagination). 107. Scheinberg IH, Jaffe ME, Sternlieb I. The use of trientine in preventing the effects of interrupting penicillamine therapy in Wilson's disease. N Engl J Med 1987; 317(4): 209-13. 108. Schilsky ML, Scheinberg IH, Sternlieb I. Prognosis of Wilsonian chronic active hepatitis. Gastroenterology 1991; 100(3): 762-7.

109. Schlaug $G$, Hefter $H$, Engelbrecht $V$, et al. Neurological impairment and recovery in Wilson's disease: Evidence from PET and MRI. J Neurol Sci 1996; 136(1-2): 129-39.

110. Seesle J, Gotthardt DN, Merle U, et al. Concomitant immune mediated phenomenon in wilson disease: Implication for monitoring of chelator therapy. J Hepatol 2012; 56: S547. 
111. Seignette WT, Haanen CA, Jansen AP, Majoor CL. [The effects of penicillamine and versenate in the treatment of Wilson's disease and lead poisoning]. Folia Med Neerl 1959; 2: 65-78.

112. Shahar H, Tan SS, Shamsul Al, Omar H. Wilson's disease (WD) in Malaysia-a single center experience. Hepatol Int 2013; 7: S113.

113. Sinha S, Taly AB, Ravishankar S, et al. Wilson's disease: Cranial MRI observations and clinical correlation. Neuroradiology 2006; 48(9): 613-21.

114. Sinha $S$, Taly AB. Withdrawal of penicillamine from zinc sulphate-penicillamine maintenance therapy in Wilson's disease: promising, safe and cheap. J Neurol Sci 2008; 264(1-2): 129-32.

115. Sintusek $P$, Chongsrisawat $V$, Poovorawan Y. Wilson's disease in Thai children between 2000 and 2012 at king chulalongkorn memorial hospital. J Med Assoc Thai 2016; 99(2): 182-87.

116. Sobesky R, Poujois A, Brunet AS, et al. Liver transplantation in severe neurological forms of Wilson disease; a multicentric French experience. Hepatology 2016; 64 (1 Supplement 1): 73A.

117. Sobesky R, Bello MD, Fernandez I, et al. Clinical presentation and outcome of wilson's disease patients in a monocentric cohort of liver reference center. Hepatology 2017; 66 (Supplement 1): $442 \mathrm{~A}$.

118. Soyer ZM, Demir K, Karaca C, et al. Wilson's disease-experience at Istanbul Faculty of Medicine O. Hepatol Int 2014; 1): S329.

119. Starosta-Rubinstein S, Young AB, Kluin K, et al. Clinical assessment of 31 patients with Wilson's disease. Correlations with structural changes on magnetic resonance imaging. Arch Neurol 1987; 44(4): 365-70.

120. Strickland GT, Blackwell RQ, Watten RH. Metabolic studies in Wilson's disease. Evaluation of efficacy of chelation therapy in respect to copper balance. Am J Med 1971; 51(1): 31-40.

121. Tai CS, Ni YH. Modality of treatment and potential outcome of wilson's disease in Taiwan: A population-based longitudinal study. J Pediatr Gastroenterol Nutr 2016; 63: S191.

122. Taly AB, Meenakshi-Sundaram S, Sinha S, Swamy HS, Arunodaya GR. Wilson disease: description of 282 patients evaluated over 3 decades. Medicine 2007; 86(2): 112-21.

123. Taylor RM, Chen Y, Dhawan A. Triethylene tetramine dihydrochloride (trientine) in children with Wilson disease: experience at King's College Hospital and review of the literature. Eur J Pediatr 2009; 168(9): 1061-68.

124. Teive HaG, De Bem RS, Muzillo D, Deguti MM, Munhoz RP, Barbosa ER. Wilson's disease in the south of Brazil: A 40 years follow-up study. Parkinsonism and Related Disorders 2012; 18: S66.

125. Trocello JM. Wilson France: A national database for Wilson's disease. Orphanet Journal of Rare Diseases Conference: 5th European Conference on Rare Diseases, ECRD 2010; 5(no pagination). 126. Valmary J, Algayres JP, Thiolet C, Coutant G, Bili H, Daly JP. The hepatic form of Wilson's disease. Seven-year treatment follow-up of 7 familial cases. [French]. Rev Med Interne 1992; 13(7): S405.

127. Van Caillie-Bertrand M, Degenhart HJ, Visser HKA. Oral zinc sulphate for Wilson's disease. Arch Dis Child 1985; 60(7): 656-59.

128. Vandriel S, Ayoub M, Ling S, Ng V, Roberts E, Kamath B. Wilsonian fulminant hepatic failure in children and adolescents: A systematic review of 274 cases. J Pediatr Gastroenterol Nutr 2017; 65 (Supplement 2): S292.

129. Viswanathan S, Puvanarajah SD, Rafia MH. Prospective look the use of trientene in Wilsons disease: A safer alternative. J Neurol Sci 2009; 285: S294-S95.

130. Walshe JM. Copper chelation in patients with Wilson's disease. A comparison of penicillamine and triethylene tetramine dihydrochloride. Q J Med 1973; 42(167): 441-52.

131. Walshe JM. Treatment of Wilson's disease with trientine (triethylene tetramine) dihydrochloride. Lancet 1982; 1(8273): 643-7.

132. Walshe JM, Yealland M. Chelation treatment of neurological Wilson's disease. Q J Med 1993; 86(3): 197-204.

133. Walshe JM. Cause of death in Wilson disease. Mov Disord 2007; 22(15): 2216-20. 
134. Wang LC, Wang JD, Tsai CR, Cheng SB, Lin CC. Clinical features and therapeutic response in Taiwanese children with Wilson's disease: 12 years of experience in a single center. Pediatr Neonatol 2010; 51(2): 124-9.

135. Wang X, Yao Y. Analysis of renal impairment in 102 children with Wilson's disease. Pediatr Nephrol 2016; 31 (10): 1815-16.

136. Weiss KH, Gotthardt D, Eckert N, Ferenci P, Stremmel W. Outcome and management of 207 pregnancies in Wilson disease. Hepatology 2011; 54: 928A-29A.

137. Weiss $\mathrm{KH}$, Schots $\mathrm{M}$, Gotthardt DN, et al. Efficacy and safety of D-penicillamine and trientine for the treatment of wilson disease. J Hepatol 2011; 54: S1.

138. Wiernicka A, Janczyk W, Dadalski M, Avsar Y, Schmidt H, Socha P. Gastrointestinal side effects in children with Wilson's disease treated with zinc sulphate. World J Gastroenterol 2013; 19(27): 4356-62.

139. Wiernicka A, Dadalski M, Janczyk W, et al. Early Onset of Wilson Disease: Diagnostic Challenges. J Pediatr Gastroenterol Nutr 2017; 65(5): 555-60.

140. Wu Y, Pham HP, Morgan S, et al. Report of the ASFA apheresis registry study on wilson's disease. J Clin Apher 2014; 29 (1): 7.

141. Xu SQ, Li XF, Zhu HY, Liu Y, Fang F, Chen L. Clinical efficacy and safety of chelation treatment with typical penicillamine in cross combination with DMPS repeatedly for Wilson's disease. Journal of Huazhong University of Science and Technology Medical Sciences 2013; 33(5): 743-7.

142. Yuce A, Kocak N, Gurakan F, Ozen H. Wilson's disease with hepatic presentation in childhood. Indian Pediatr 2000; 37(1): 31-6.

143. Yuce A, Uslu N, Balamtekin N, et al. Wilson's disease in children: Monocentric experience with analysis of 114 children over a 18 years period. J Pediatr Gastroenterol Nutr 2010; 50: E144. 144. Zhang J, Li L, Chen H, Yang W. Clinical efficacy and safety of Gandouling plus low-dose Dpenicillamine for treatment of Wilson's disease with neurological symptoms. J Tradit Chin Med 2018; 38(1): 89-94.

145. Roberts EA, Schilsky ML. Diagnosis and treatment of Wilson disease: An update. Hepatology 2008; 47(6): 2089-111.

146. Ferenci P, Czlonkowska A, Stremmel W, et al. EASL Clinical Practice Guidelines: Wilson's disease. J Hepatol 2012; 56(3): 671-85.

147. Nagral A, Sarma MS, Matthai J, et al. Wilson's Disease: Clinical Practice Guidelines of the Indian National Association for Study of the Liver, the Indian Society of Pediatric Gastroenterology, Hepatology and Nutrition, and the Movement Disorders Society of India. Journal of Clinical and Experimental Hepatology 2019; 9(1): 74-98.

148. Socha P, Janczyk W, Dhawan A, et al. Wilson's Disease in Children: A Position Paper by the Hepatology Committee of the European Society for Paediatric Gastroenterology, Hepatology and Nutrition. J Pediatr Gastroenterol Nutr 2018; 66(2): 334-44.

149. Czlonkowska A, Gajda J, Rodo M. Effects of long-term treatment in Wilson's disease with Dpenicillamine and zinc sulphate. J Neurol 1996; 243(3): 269-73.

150. Medici $V$, Trevisan CP, D'inca R, et al. Diagnosis and management of Wilson's disease: results of a single center experience. J Clin Gastroenterol 2006; 40(10): 936-41.

151. Merle U, Schaefer M, Ferenci P, Stremmel W. Clinical presentation, diagnosis and long-term outcome of Wilson's disease: a cohort study. Gut 2007; 56(1): 115-20.

152. Bruha R, Marecek Z, Pospisilova L, et al. Long-term follow-up of Wilson disease: natural history, treatment, mutations analysis and phenotypic correlation. Liver International 2011; 31(1): 83-91.

153. Weiss KH, Gotthardt DN, Klemm D, et al. Zinc monotherapy is not as effective as chelating agents in treatment of Wilson disease. Gastroenterology 2011; 140(4): 1189-98.

154. Rodriguez B, Burguera J, Berenguer M. Response to different therapeutic approaches in Wilson disease. A long-term follow up study. Ann Hepatol 2012; 11(6): 907-14.

155. Czlonkowska A, Litwin T, Karlinski M, Dziezyc K, Chabik G, Czerska M. D-penicillamine versus zinc sulfate as first-line therapy for Wilson's disease. Eur J Neurol 2014; 21(4): 599-606. 
156. Ranucci G, Di Dato F, Spagnuolo MI, Vajro P, lorio R. Zinc monotherapy is effective in Wilson's disease patients with mild liver disease diagnosed in childhood: a retrospective study. Orphanet J Rare Dis 2014; 9: 41.

157. Iorio R, D'ambrosi M, Marcellini M, et al. Serum transaminases in children with Wilson's disease. J Pediatr Gastroenterol Nutr 2004; 39(4): 331-36.

158. Cope-Yokoyama S, Finegold MJ, Sturniolo GC, et al. Wilson disease: histopathological correlations with treatment on follow-up liver biopsies. World I Gastroenterol 2010; 16(12): 1487-94. 159. Sini M, Sorbello O, Sanna F, et al. Histologic evolution and long-term outcome of Wilson's disease: results of a single-center experience. Eur J Gastroenterol Hepatol 2013; 25(1): 111-7. 